Review

\title{
Exploiting the Natural Properties of Extracellular Vesicles in Targeted Delivery towards Specific Cells and Tissues
}

\author{
Pablo Lara ${ }^{1,2,3}$, Alan B. Chan ${ }^{1}$, Luis J. Cruz ${ }^{2}$, Andrew F. G. Quest ${ }^{3,4, *(1)}$ and
} Marcelo J. Kogan ${ }^{3,5, *}$

1 Percuros B.V., 2333 CL Leiden, The Netherlands; p.lara_arenas@lumc.nl (P.L.); achan@percuros.com (A.B.C.)

2 Translational Nanobiomaterials and Imaging (TNI) Group, Radiology Department, Leiden University Medical Center, Albinusdreef 2, 2333 ZD Leiden, The Netherlands; L.J.Cruz_Ricondo@lumc.nl

3 Advanced Center for Chronic Diseases (ACCDiS), University of Chile, Santos Dumont 964 Independencia, 8380000 Santiago, Chile

4 Laboratory of Cellular Communication, Program of Cell and Molecular Biology, Center for Studies on Exercise, Metabolism and Cancer (CEMC), Institute of Biomedical Sciences (ICBM), Faculty of Medicine, University of Chile, Av. Independencia 1027, 8380453 Santiago, Chile

5 Departamento de Química Farmacológica y Toxicológica, Facultad de Ciencias Químicas y Farmacéuticas, Universidad de Chile, Santos Dumont 964 Independencia, 8380494 Santiago, Chile

* Correspondence: aquest@med.uchile.cl (A.F.G.Q.); mkogan@ciq.uchile.cl (M.J.K.); Tel.: +56-229-789-636 (A.F.G.Q.); +56-229-782-897 (M.J.K.)

Received: 29 September 2020; Accepted: 16 October 2020; Published: 26 October 2020

check for updates

\begin{abstract}
Extracellular vesicles (EVs) are important mediators of intercellular communication that participate in many physiological/pathological processes. As such, EVs have unique properties related to their origin, which can be exploited for drug delivery applications in cell regeneration, immunosuppression, inflammation, cancer treatment or cardioprotection. Moreover, their cell-like membrane organization facilitates uptake and accumulation in specific tissues and organs, which can be exploited to improve selectivity of cargo delivery. The combination of these properties with the inclusion of drugs or imaging agents can significantly improve therapeutic efficacy and selectivity, reduce the undesirable side effects of drugs or permit earlier diagnosis of diseases. In this review, we will describe the natural properties of EVs isolated from different cell sources and discuss strategies that can be applied to increase the efficacy of targeting drugs or other contents to specific locations. The potential risks associated with the use of EVs will also be addressed.
\end{abstract}

Keywords: extracellular vesicles (EVs); exosomes; microvesicles; targeting; tracking; drug delivery; theranostics

\section{Introduction}

The ability of drugs to exert their therapeutic effects is limited by their stability in circulation and their capacity to cross cellular barriers and reach the desired tissue. In cancer, for example, most therapies have limited efficacy as drugs have low selectivity, which results in a considerable number of side effects in the organism. For this reason, efforts currently focus on the development of therapeutic agents that can be targeted to specific sites in the body. The availability of such agents would improve the therapeutic opportunities, the efficiency of the treatment and the survival of the patients, while reducing undesired side effects.

The utilization of nanomaterials has revolutionized research in drug delivery due to the physical and chemical characteristics of nanoscale materials. Moreover, nanoparticles (NPs) have the potential 
to combine multiple therapeutic functions on the same platform, for example by incorporating drugs or agents that increase cell penetration, labelling agents or biopolymers, among others. Current strategies aim to develop intelligent nanomaterials that incorporate multiple functions and are capable of selectively reaching the therapeutic target, diagnosing the disease and carrying out treatment simultaneously.

Despite the great potential of nanomaterials, the majority of synthetic NPs developed never reach clinical trials, because they fail to overcome the multiple barriers present in the organism. Most of the nanoparticles are captured by the mononuclear phagocytic system and retained in the liver and spleen for subsequent elimination. The NPs that manage to overcome these barriers must cross others, such as the blood-brain barrier that prevents the passage of $99 \%$ of the molecules. Furthermore, to reach their intended cellular location, NPs are confronted with other obstacles, such as poor vascularization in the case of cancer cells, cell impermeability, endosomal escape, as well as resistance mechanisms involving efflux pumps [1].

As a result, there is a need for nanovehicles with the ability to evade these multiple barriers in the organism and at the same time increase selective targeting to specific cellular locations. Recently, the utilization of extracellular vesicles (EVs) for drug delivery in different fields of therapeutics has gained popularity as they are natural carriers of biological material between cells [2-11]. These vesicles are secreted by almost all cell types and can be isolated from different body fluids, such as urine, blood and cerebrospinal fluid, as well as from other external sources, such as plants, fruits and milk. The EV contents are determined by their origin and include various cell-specific molecules, such as integrins, immunoglobulin family members, heat-shock proteins, RNA, miRNA, antigen-presenting proteins and tetraspanins, which make them interesting for diagnostics and immunotherapy. EVs have also been shown to be highly tunable structures and efficient vehicles for drug delivery [12]. As the homing properties of these vesicles are determined by specific cell-membrane components, the drug selectivity can be improved by isolating EVs with natural tropism to the brain, liver, lung, cancer cells or others. These properties can be further enhanced by loading EVs with drugs, lipids, peptides, NPs, imaging agents or by engineering cells to produce EVs that express a specific molecule to improve their targeting or therapeutic effectiveness [13-16].

Designing a good strategy for targeted therapy can be challenging when considering the multiple alternatives of EV-producing cells or biological fluids, the different properties of each type of EV and the targeting/drug-loading methods currently available. Choosing the most appropriate strategy depending on the therapeutic target can have a great impact on therapy outcome. In this review, we will focus particularly on the utilization of the natural properties of EVs to favor targeting and efficacy towards specific cells and discuss different strategies to enhance and combine that potential for cell-specific targeting, drug delivery and imaging purposes. Further, the potential risks and limitations in the use of EVs will be discussed.

\section{Extracellular Vesicles}

EVs are particles surrounded by a lipid bilayer which are released by most eukaryotic and prokaryotic cells as a means of intercellular communication in an evolutionarily conserved process $[17,18]$. EVs can be found in different body fluids, such as blood, saliva, urine, seminal fluid, and breast milk. Importantly, increasing evidence points towards their potential to serve as biomarkers in the diagnosis and prognosis of a variety of pathologies [19-23]. These vesicles are capable of transporting cytosolic and membrane proteins, including receptors and major histocompatibility complexes, as well as DNA fragments and RNA molecules (mRNA, microRNA and other non-coding RNAs) and even organelles (large EVs) [19,24-26]. Moreover, EVs display different properties depending on the cell type from which they were isolated. For instance, EVs from immune cells express markers, such as MHC or CD3 molecules, on their surface, which allow them to trigger specific responses in the immune system $[19,27]$. 
According to their biogenesis, EVs can be separated into three main groups-exosomes, microvesicles (MVs) and apoptotic bodies. Exosomes are stored in multivesicular bodies (MVBs) and subsequently released into the extracellular space when these bodies merge with the plasma membrane. MVs are formed by shedding from the plasma membrane and apoptotic bodies are released by dying cells. Since there is still no consensus on a specific marker for EV-specific subtypes [17], the international society for extracellular vesicles recommends using a general terminology rather than assigning the EVs to a particular biogenesis pathway. It has also been suggested to segregate them into subcategories according to their size (small, medium or large EVs), their density or their biochemical composition (i.e., CD63+). However, given that there is still no standardized nomenclature for the different vesicle subpopulations, we will use the more general term and refer to them as EVs throughout this review, focusing on summarizing data from publications relating to exosomes and MVs.

\section{EVs for Drug Delivery}

EVs have great potential for drug delivery, due to their natural properties and versatility which we will address in the following sections. These vesicles have an intrinsic capacity to cross biological barriers, are capable of transporting various components and protect their content from degradation $[26,28,29]$. As natural regulators of the cellular microenvironment, they also play an important role in cellular communication [30-32]. EVs are endowed with specific properties related to their biogenesis that can be used to improve the effectiveness of therapy [4,11,33-37]. Examples of this are oral absorption (milk EVs [11]), anti-inflammatory effect (grape EVs [38]), and presence of specific receptors (e.g., transferrin, major histocompatibility complexes, folate [27,39-41]). Some EVs can also increase their residence time in circulation by displaying antiphagocytic surface markers to evade clearance by the mononuclear phagocytic system [42]. Different compounds can be incorporated into such vesicles, such as drugs, nanoparticles, lipids, proteins, peptides, RNA, siRNA and fluorescent markers [13-15]. Lipophilic drugs or compounds will preferentially intercalate into the membrane bilayer, while hydrophilic compounds will prefer the lumen. Additionally, the surface of the EVs can be modified to improve their functionality. Various techniques have been proposed to favor the inclusion of therapeutic molecules in EVs. One of the most used is electroporation, which involves applying an electric field to a suspension containing the EVs and the active molecule, to create pores that facilitate movement of the drug to the vesicle interior [43]. Electroporation has the advantage of not requiring a vector to incorporate the drug and benefits from the technology developed to include molecules in liposomes. However, it can affect colloidal stability, causing EV properties to be lost or altered. It can also promote aggregation of the loaded molecules such as siRNA and it is overall difficult to scale up $[19,44,45]$. Some authors have also proposed the possibility of including drugs in EVs by sonication or direct incubation of the vesicles with the active ingredients [6,46]. The sonication method is useful for encapsulating lipophilic and hydrophilic drugs because the vibrations disrupt the membranes and facilitate entry. However, this method is only applicable for small molecules and might cause the adhesion of the molecule to the EV surface, which could change the biodistribution and release of the drug $[19,47]$. On the other hand, direct incubation is one of the simplest techniques and usually does not require the addition of any additional reagents; however, it is also limited to small and generally lipophilic compounds [19,46]. Another method used is cell transfection that involves transferring specific genes to the parental EV-producing cells where the molecule of interest is generated and then included during EV biogenesis [48,49]. Currently, there are genetic editing tools that facilitate the use of this technique; however, they are usually time consuming and difficult to scale up. Although the cell transfection technique was originally proposed exclusively to encapsulate genetic material inside EVs, some authors have proposed using the same concept to incorporate other types of active ingredients. For example the antineoplastic drug Paclitaxel has been incorporated into stromal mesenchymal cells, which were resistant to the drug and incorporated it into EVs, which displayed cytotoxic effects against cancer cells [50]. Another recent example is the incorporation of gold nanoparticles (AuNPs), which were incubated and taken up by cells to promote their passage through the MVB and inclusion 
in EVs [13]. The pre-cargo-loading strategies permit obtaining EVs containing therapeutic compounds without the need for membrane-disruptive techniques. Further, such EVs can then be modified post-isolation with lipophilic drugs, fluorescent markers or targeting agents (Figure 1).

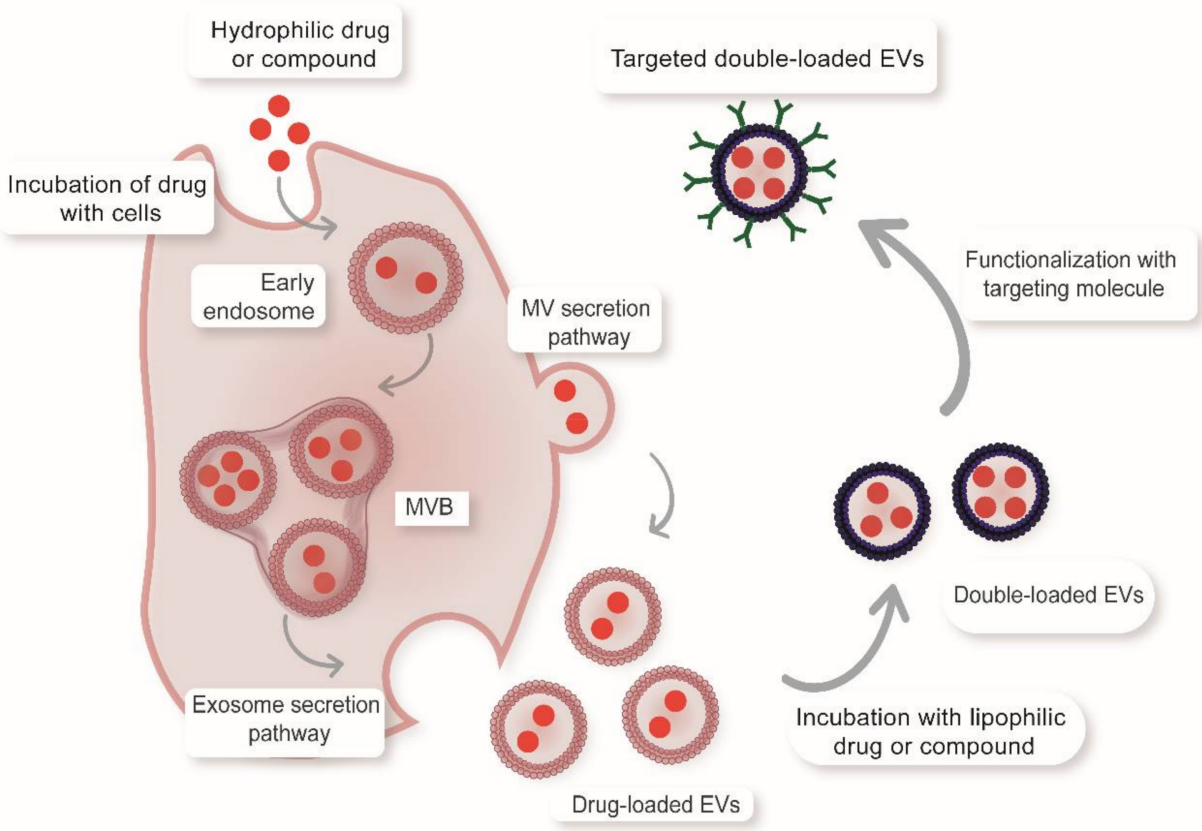

Figure 1. Simultaneous incorporation of hydrophilic drugs, lipophilic compounds and targeting agents into EVs. Pre-cargo and post-cargo strategies can be combined to simultaneously load EVs with multiple therapeutic agents. Loading hydrophilic molecules can be achieved without membrane surface disruption by incubating cells with the cargo molecules. After the cargo is incorporated by the cells, it may follow the endocytic pathway and be released inside exosomes or be directly liberated from the cell surface inside MVs. The resulting EVs carrying the therapeutic cargo can additionally be loaded with small lipophilic molecules, such as a fluorescent dyes or drugs by direct incubation strategies. Finally, the resulting double-loaded EVs can be externally modified with targeting agents (e.g., peptides, antibodies, drugs) by chemical approaches.

\section{Relevant Parameters Involved in the Application of EVs for Drug Delivery}

\subsection{Targeting Properties}

As mentioned above, EVs can be loaded with multiple therapeutic agents simultaneously (e.g., targeting peptides, drugs and imaging agents) which makes them highly versatile vectors for drug delivery strategies. However, what makes EVs even more interesting in comparison to other drug delivery vehicles is the variety of natural properties they possess. Although their genesis is still not well understood, available evidence suggests that they have multiple therapeutic benefits for targeting strategies, such as enhanced cellular uptake, organ tropism and immunomodulation. These properties are endowed by the presence of different adhesion and immunoregulatory molecules, as well as cell-specific receptors, which can be used to enhance accumulation in specific tissues. Examples of the latter are shown in Figure 2 and Table 1. In the next section, we will focus on these natural properties and discuss how they can be finetuned to specific applications by isolating the EVs from different cell types. 


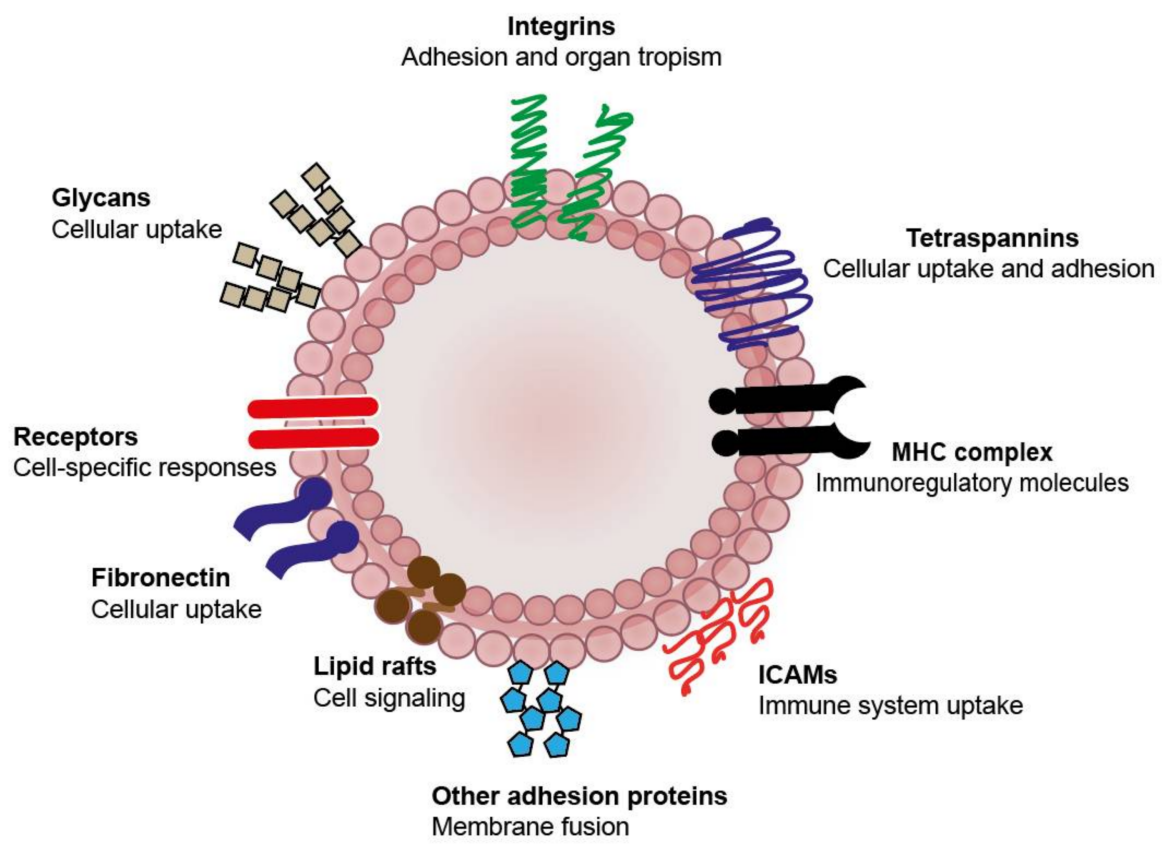

Figure 2. Naturally occurring features of EVs for targeting applications. EVs contain several surface molecules than will determine their systemic distribution and targeting to specific cell populations. Tetraspannins, glycans, fibronectin and intercellular adhesion molecule (ICAM) composition modulate their uptake, while integrins play an important role in defining their accumulation in specific organs. Immunoregulatory molecules influence their recognition by immune cells which can have an impact on their distribution and uptake. Lipids, receptors and cell-specific proteins can also modulate the responses of target cells by activating multiple cell signaling pathways.

\subsubsection{EV Cellular Uptake}

The uptake of EVs is a complex process that involves a combination of different pathways [51], such as caveolae-dependent endocytosis, clathrin-dependent endocytosis, phagocytosis, pinocytosis, receptor-mediated endocytosis and fusion with the plasma membrane [52-56]. This variety of mechanisms provide EVs with some significant advantages in comparison to other synthetic drug delivery systems with respect to their mode of interaction with host cells and their ability to transfer therapeutic molecules [57]. There is still no consensus on which of the uptake mechanisms is more important; however, available evidence shows that internalization is an active process that is significantly decreased at $4{ }^{\circ} \mathrm{C}$ or after blocking protein interactions using specific antibodies. The high degree of EV heterogenicity depending on their cellular origin contributes significantly to their uptake and available evidence suggests that this can be selectively enhanced by choosing specific cell models $[13,58]$.

\subsubsection{Cell Type-Dependent Uptake}

There is increasing evidence that the specificity of EV uptake depends on their cellular origin [59-61]. For instance, EVs from mesenchymal stem cells are taken up more efficiently by their own cells when compared to other immune cells [62]; neuroblastoma EVs are endocytosed preferentially by glial cells [63]; ovarian cancer EV cells also showed increased uptake by tumor cells when compared to epithelial cell-derived EVs [64]. A recent study compared the uptake of multiple-source EVs with their corresponding cells and showed that melanoma EVs were taken up more efficiently by melanoma cells rather than immune cells, fibroblast and endothelial cells [13]. Interestingly, the uptake of colon adenocarcinoma EVs (by melanoma cells) was also higher than non-tumor EVs, suggesting that cancer-specific molecules may play an important role in promoting the uptake of these vesicles by 
tumor cells. Although there is still not enough evidence for the cell type-specific uptake in vivo models, it could potentially represent an effective strategy to direct drugs towards specific cells and reduce the therapy-associated side effects. The mechanisms involved in the preferential uptake of EVs are also not totally understood; however, there is evidence that tetraspanins and integrins play an important role in target selection. For example, Tspan8 is important for the uptake and targeting towards endothelial, kidney and pancreas cells, while CD151 is more important for lung and lymph node cell uptake [65]. On the other hand, EV expression of other surface proteins, such as ICAMs, has been implicated in enhanced uptake by immune cells [66]. Alternatively, surface heparan sulfate proteoglycans have been shown to play an important role in the uptake by cancer cells [67]. We summarized some examples of the evidence for enhanced uptake of specific EVs by different cells in Table 1. As we discuss in the following sections, improving tracking techniques will be essential to corroborate this hypothesis and exploit EV potential to target specific cells.

\subsubsection{EV Biodistribution}

EVs also have natural advantages relating to their biodistribution, such as their reduced aggregation potential and the ability to avoid clearance by the reticuloendothelial system (RES) by presenting antiphagocytic markers [42]. Their small size favors their accumulation in highly vascularized tissues with low lymphatic drainage such as tumors, due to the enhanced permeability and retention (EPR) effect, which can be used as a strategy to increase targeting towards tumors. The distribution of the EVs depends on different factors, such as the administration route, cellular origin, concentration and time. In circulation, most EVs are captured by the mononuclear phagocytic system and delivered primarily to the liver, followed by spleen, lungs and the gastrointestinal tract [37]. This pattern of accumulation is similar to that of other NPs, such as synthetic liposomes, suggesting that the size also plays an important role in the uptake of EVs. The administration route is important in determining the biodistribution and accumulation of the EVs. For instance, intraperitoneal administration results in increased accumulation in the pancreas, while subcutaneous injection can result in increased accumulation in the GI tract [37]. Intravenous injection is the most studied administration route and usually results in increased delivery to the liver and spleen and reduced accumulation in pancreas [37]. Intratumoral administration has also been used to facilitate tumor accumulation, which is elevated in comparison with other NPs, such as liposomes [57]. Intranasal administration is also interesting as an effective strategy to promote EV-delivery to the brain [3]. Oral administration represents the overall preferred route of administration in patients, but is one of the most challenging options due to the multiple barriers of the digestive system. Curiously, EVs isolated from plants, milk and intestinal epithelial cells have an unique potential to reach the circulation after oral administration, which makes them interesting carriers to improve the bioavailability of drugs [68]. There is currently limited information available concerning the clearance of the extracellular vesicles due to technical difficulties related to their rapid uptake and the non-specific transfer of the fluorescent dyes to extracellular proteins [69]. Recently, some authors have shown that EVs have a short half-life in circulation and their blood concentration is determined by a complex balance between secretion into the bloodstream and rapid blood clearance (fast uptake by multiple cells) [70].

\subsubsection{EV Organ Tropism}

The cell of origin of the EVs also has an important effect on their distribution and tropism to specific organs. For example, EVs from dendritic cells show increased accumulation in spleen, while melanoma EVs are more likely to accumulate in lungs [37]. Interestingly, some EVs show tropism towards organs related to their cellular origin (Table 1). Endothelial EVs from the brain can accumulate in the cerebral tissue [71], while melanoma EVs target preferentially melanoma metastases [13]. MSC-EVs showed increased accumulation in kidneys of mice with acute kidney injury, suggesting that the presence of a particular disease also affects their biodistribution [72]. Although the specific targeting of EVs is still not totally understood, there have been some advances in discovering important molecules 
involved in the process. For instance, integrins are important cell adhesion molecules involved in organ-specific metastasis of tumor cells [73,74]. Interestingly, as shown in Table 1, different adhesion molecules have an important impact in the organ tropism (e.g., lung, liver and pancreas). For example, the presence of $\alpha 6 \beta 4$ and $\alpha 6 \beta 1$ is important in EV tropism to the lungs, while expression of $\alpha \mathrm{v} \beta 5$ promotes accumulation in the liver [74,75]. There is also evidence that CD47 expression in EVs is important for avoiding phagocytosis, increasing time in circulation and uptake by micropinocytosis [42]. It is important to mention that a controversy exists concerning the distribution of EVs from different cell sources and, contrary to what we mentioned above, some articles reported a similar distribution of EVs isolated from different cell models [76,77]. Therefore, more information and better experimental approaches are needed to test this hypothesis

Table 1. Examples of natural EV targeting to specific cells.

\begin{tabular}{|c|c|c|}
\hline Isolated from/Enriched in & Targeting to & Reference \\
\hline Human placental MSCs & MSCs & [62] \\
\hline Neuroblastoma N2a cells & Glial cells & [63] \\
\hline Brain endotelia bEND. 3 cells & Brain & [71] \\
\hline Bone marrow DCs & Spleen & [37] \\
\hline Ovarian cancer SKOV3 cells & SKOV3 cells & [64] \\
\hline Melanoma B16F10 cells & B16F10 cells, lungs and pulmonary metastasis & {$[13,37]$} \\
\hline Melanoma B16BL6 cells & B16BL6 cells & [60] \\
\hline Bone marrow MSCs & $\begin{array}{l}\text { kidneys on acute kidney injury model and M2 } \\
\text { type macrophages on injured spinal cord }\end{array}$ & {$[72,78]$} \\
\hline Fibroblast CD47+ & Pancreatic cancer & [42] \\
\hline Breast cancer MDA-MB-231 under hipoxia & Hypoxic MDA-MB-231 cells & [79] \\
\hline Heparan sulfate proteoglicans on hepatic cell lines AML12 and MLP29 & $\begin{array}{l}\text { Hepatic (Huh7), fibroblastoid (M1) cells and } \\
\text { osteoblast (U2-OS) cells }\end{array}$ & [67] \\
\hline Tspan 8 expresion in pancreatic adenocarcinoma cells BSp73AS & Pancreas and lung & [65] \\
\hline Fibronectin in microvascular endothelial cells MVECs & Oligodendrocyte precursor cells & [80] \\
\hline ICAM on bone marrow DCs & Naïve T cells & [66] \\
\hline$\alpha \mathrm{v} \beta 5$ expression on multiple cells (refeer to publication) & Liver tropism & [75] \\
\hline$\alpha 6 \beta 4$ and $\alpha 6 \beta 1$ expression on multiple cells (refeer to publication) & Lung tropism & [75] \\
\hline
\end{tabular}

\subsection{Therapeutic Properties}

\subsubsection{Antitumoral Effects}

EVs are involved in various processes related to the development and progression of cancer. For this reason, they are of great interest as possible diagnostic markers and potential candidates for directed therapy against malignant cells. Their natural potential to accumulate in specific tissues (as described above) makes them ideal systems to improve the delivery towards tumors located in zones that are difficult to access, such as the brain or hypoxic tumor sites. As other NPs, EVs benefit from the enhanced permeability and retention (EPR) effect, which allows them to passively accumulate in the tumors. As we mentioned before, there is evidence that tumor EVs can actively and preferentially target other tumor cells, which is an interesting approach for drug delivery purposes. Moreover, EVs have been used for antigen presentation strategies (vaccinations strategies) and to promote inflammation or cytotoxic effects in tumor cells (inflammation strategies) as we will summarize below and in Figure 3. 


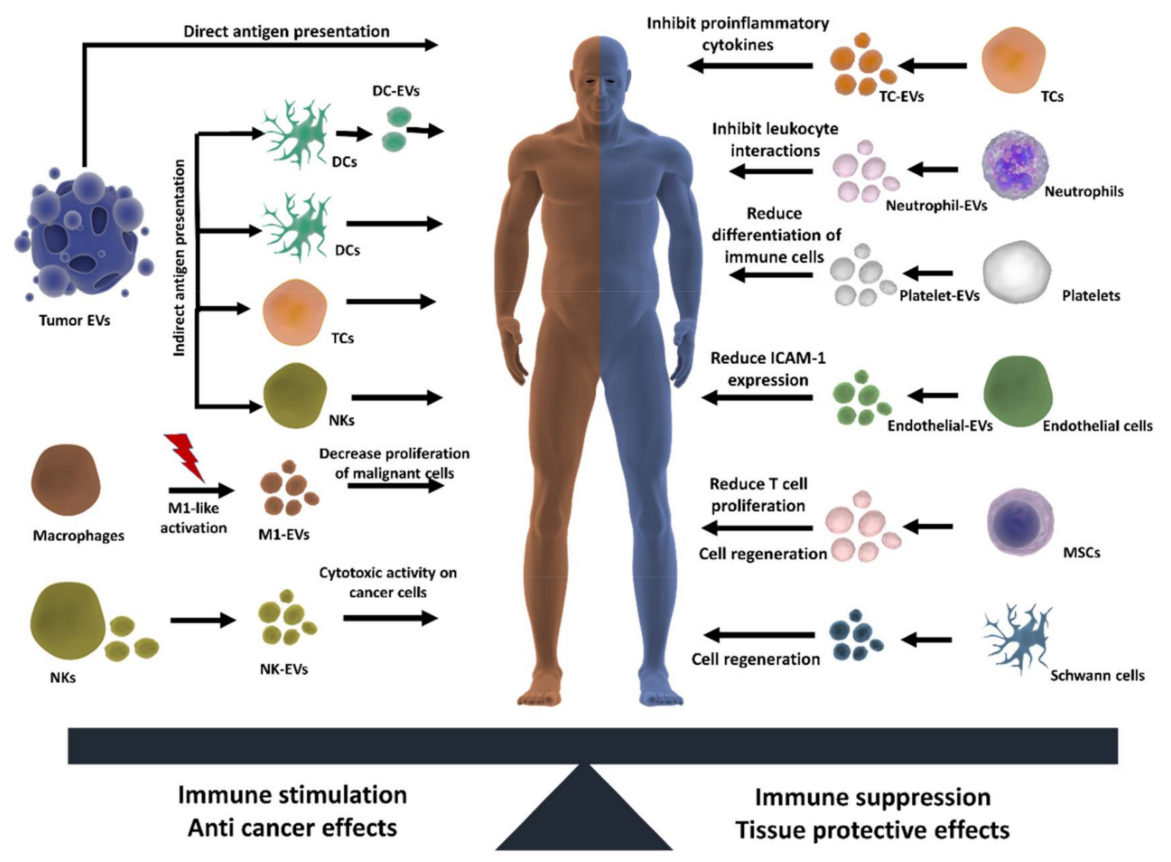

Figure 3. Using the natural features of EVs for therapy and tissue repair. EVs play a key role in modulating cellular responses by enhancing or suppressing immune responses in target cells. These properties can be exploited for therapeutic purpose by isolating EVs with the desired characteristics (e.g., antitumoral activity, cell regeneration or cardioprotection). Combining these effects together to modulate the target microenvironment is an interesting approach to reduce the side effects of drugs, improve efficacy and generate more personalized medicines. DCs: dendritic cells; NKs: natural killer cells; TCs: T cells; MSCs: mesenchymal stem cells.

Antigen presentation strategies. Tumor cell-derived EVs (TEVs) have been shown to carry cancer antigens that promote antitumor effects by stimulating dendritic cells (DCs), which is an interesting strategy to enhance the immune responses against cancer cells [81]. For example, patient TEVs have been shown in clinical trials to produce specific antitumor immune cell responses [82]. As tumor antigens on TEVs are recognized by immune cells, once sensitized, they can selectively target and destroy malignant cells. Therefore, this strategy holds great promise to be used in the future as a way to develop cancer vaccines. Other authors have shown that EVs from malignant cells can also activate $\mathrm{T}$ lymphocytes and NK cells to facilitate the transfer of antigens to DCs. The antigen-activated immune cells can be administrated to the patient/animal (instead of tumor EVs) which subsequently increase the immune response. In this way, the side effects related to the administration of malignant EVs can be avoided $[8,83,84]$. Another related strategy involves using immune cell-derived EVs, as they can express specific markers, such as MHC molecules or CD3 (important for immune effects) and can be previously activated to generate a specific antitumoral effect. An example of such an approach which has reached clinical trials is using tumor cell peptides to activate DCs and then isolating EVs from activated-DCs to promote an immune response against cancer $[19,83,85,86]$.

Inflammation strategies. As natural killers, NK cells are provided with several lytic proteins that are used to destroy pathogens. NK-EVs not only possess specific NK markers but also contain proteins, such as FasL, perforins, granzymes and granulysin, which promotes cytotoxic activity and have been effectively used to kill cancer cells [87]. The utilization of macrophage-derived EVs has also emerged as a novel therapeutic approach, because of their ability to modulate the tumor microenvironment and increase the sensitivity of tumor cells to drugs. While tumor-associated macrophages have been shown to promote tumor progression, angiogenesis, immunosuppression and metastasis, a study by Cheng et al. describes that their EVs actually promote inflammation-related responses, which can enhance 
immunotherapy effects against cancer cells [88]. Moreover, other studies suggest that by using EVs from macrophages polarized towards an M1-like phenotype (which has antitumoral features), it is possible to decrease the proliferation of malignant cells, enhance immune responses and increase the effectiveness of drugs [89].

\subsubsection{Modulation of Inflammation}

While acute inflammation plays a positive role in our defense systems against pathogens, prolonged inflammation can lead to the development of several chronic diseases, such as arthritis, cancer, Alzheimer, diabetes and cardiovascular diseases. Extracellular vesicles play an important role as mediators of pro-inflammatory or anti-inflammatory responses which can be exploited to treat chronic diseases (Figure 3). For instance, T cell-derived EVs inhibit production of the pro-inflammatory cytokines IL-1 $\beta$ and TNF [90], while neutrophil-derived EVs contain anti-inflammatory proteins that inhibit leukocyte/endothelium interactions [91]. Platelets also participate in important anti-inflammatory effects by driving the differentiation status of macrophages, dendritic cells and T cells towards less-reactive states [92,93]. Endothelial EVs promote anti-inflammatory effects by reducing ICAM-1 expression [94] and together with platelets have been attributed a protective role in sepsis [95]. MSC-derived EVs have been reported to reduce T lymphocyte proliferation, as well as the percentage of CD4+ and CD8+ T cell subsets [96]. Macrophage EVs also play an important role in immune surveillance after exposure to mycobacterial infections as they transport bacterial components that can induce pro-inflammatory responses [18,97]. Interestingly, some authors proposed that EVs could also be used to modulate aging speed by regulating age-related pro-inflammatory status [98,99]. Evidence suggest that EVs are involved in a crosstalk between telomere dysfunction and inflammation which contributes to aging-related disorders [100]. As EV miRNA profiles changes during aging, the use of EV from young donors could be an interesting approach to increase cell longevity $[98,99,101]$.

\subsubsection{Cell Regeneration}

Mesenchymal stem cells (MSCs) have revealed great potential in tissue regeneration. Their administration, however, may lead to serious side effects, such as differentiation into undesirable tissues, or inducing unfavorable immune responses. Some authors have indicated that MSCs induce such effects by paracrine signaling rather than direct cell-to-cell interactions. This has led to the hypothesis that their therapeutic effect may be mediated by EVs [102]. Indeed, MSC-EVs may represent an interesting approach to avoid the side effects of whole cell therapies. For example, MSC-EVs have been shown to accelerate skeletal muscle regeneration and promote hepatic regeneration after liver injury $[103,104]$. By equilibrating peripheral immune responses, MSC-EVs can also improve neuronal regeneration and prevent post-ischemic immunosuppression after intravenous administration [102]. Other EVs are also provided with interesting features for cell regeneration, such as endothelial EVs which can increase the number and differentiation state of human endothelial progenitor cells [105]. Schwann cell-derived EVs (SC-EVs) are also interesting, as they have been shown to enhance axonal regeneration and neuronal survival after the application of damaging stimuli to neurons [106]. Interestingly, these effects were specific for SC-EVs and mediated by the inhibition of the GTPase Rho, involved in axon retraction. These examples suggest that EVs from different sources may be useful in promoting tissue regeneration after damage (Figure 3).

\subsubsection{Cardiovascular Diseases}

EVs are implicated in cardiovascular homeostasis, where they play an important role in preventing damage during stress conditions, which makes them interesting candidates for cardioprotective applications. Evidence suggest that EVs from cardiac progenitor cells can inhibit cardiomyocyte apoptosis and improve cardiac function after myocardial infarction [107]. MSC-EVs have also shown great potential in preventing cardiac tissue damage. Some remarkable findings are their potential to increase myocardial viability and reduce ischemia/reperfusion damage to the myocardia [108] 
and kidney [109]. The mechanism of cardioprotection is suggested to be linked to a decrease in oxidative stress and activation of the PI3K/Akt pathway, which increases viability and promotes remodeling of the myocardia [110]. Interestingly, such beneficial functions also apply to renal stress conditions, as MSC-EVs can protect against acute tubular injury [111] and reduce damage of ischemia/reperfusion-induced acute renal failure [112].

\subsection{Modulating the Targeting of EVs}

EV targeting can be modified using different approaches, such as changing the isolation method, subjecting the cells to stress prior to isolation or changing the administration route. Targeting of EVs can be further changed by introducing structural modifications to enhance different properties, such as stability and homing towards specific cells. Combining the natural properties of EVs with pre-cargo and post-cargo strategies can enhance the potential of EVs for therapeutic applications, targeting and imaging.

\subsubsection{Isolation Conditions}

In addition to the cell source, it is also important to consider the isolation conditions as they can have an important impact on the uptake or biodistribution of the EVs. For example, EVs isolated by ultrafiltration and ultracentrifugation yielded different purity, and protein/vesicle ratios which resulted in different patterns of in vivo accumulation in lungs [113]. Antibody-based isolation methods can also impact on EV targeting as they can select for specific vesicle subpopulations (e.g., CD63+ vesicles), which may lead to alterations in the distribution pattern. Subjecting the cells to different stimuli before isolation has also been shown to have important effects on EV targeting. For instance, the uptake by hypoxic tumor cells can be enhanced by using EV-derived from cells subjected to hypoxia prior to isolation [79]. Similar effects have also been observed when using EVs from cells exposed to other stress conditions, such as radiation, thermal stress or changing the $\mathrm{pH}$ of the medium $[114,115]$. The mechanisms that explain the increased targeting after stress are not totally understood; however, there is evidence that the cargo content of EVs can change under these conditions [116]. For example, after $\mathrm{pH}$ stress VEGF accumulates inside EVs in its bioactive form, which favors the stimulation of recipient cells [114]. The lipid composition is also modified under such conditions, changing EV rigidity and increasing fusion efficiency [115]. Finally, the protein HSP90, which is involved in adhesion and migration, is also increased after heat-shock stress [116,117]. Subjecting cells to stress may not only improve targeting but also their therapeutic properties. ER stress, for example, can promote the release of pro-inflammatory EVs that stimulate macrophage chemotaxis by interfering with sphingosine-1-phosphate signaling [118].

\subsubsection{Engineering Targeting}

As with other drug delivery systems, the natural targeting of EVs can be manipulated to improve their uptake and biodistribution. The surface modification or addition of a targeting ligand can be achieved by direct strategies involving the manipulation of isolated EVs or indirect strategies involving the modification of cells before EV isolation. The most common strategies are summarized in Figure 4 and discussed below. We also provide some examples of multiple engineered targeting strategies in Table 2. 


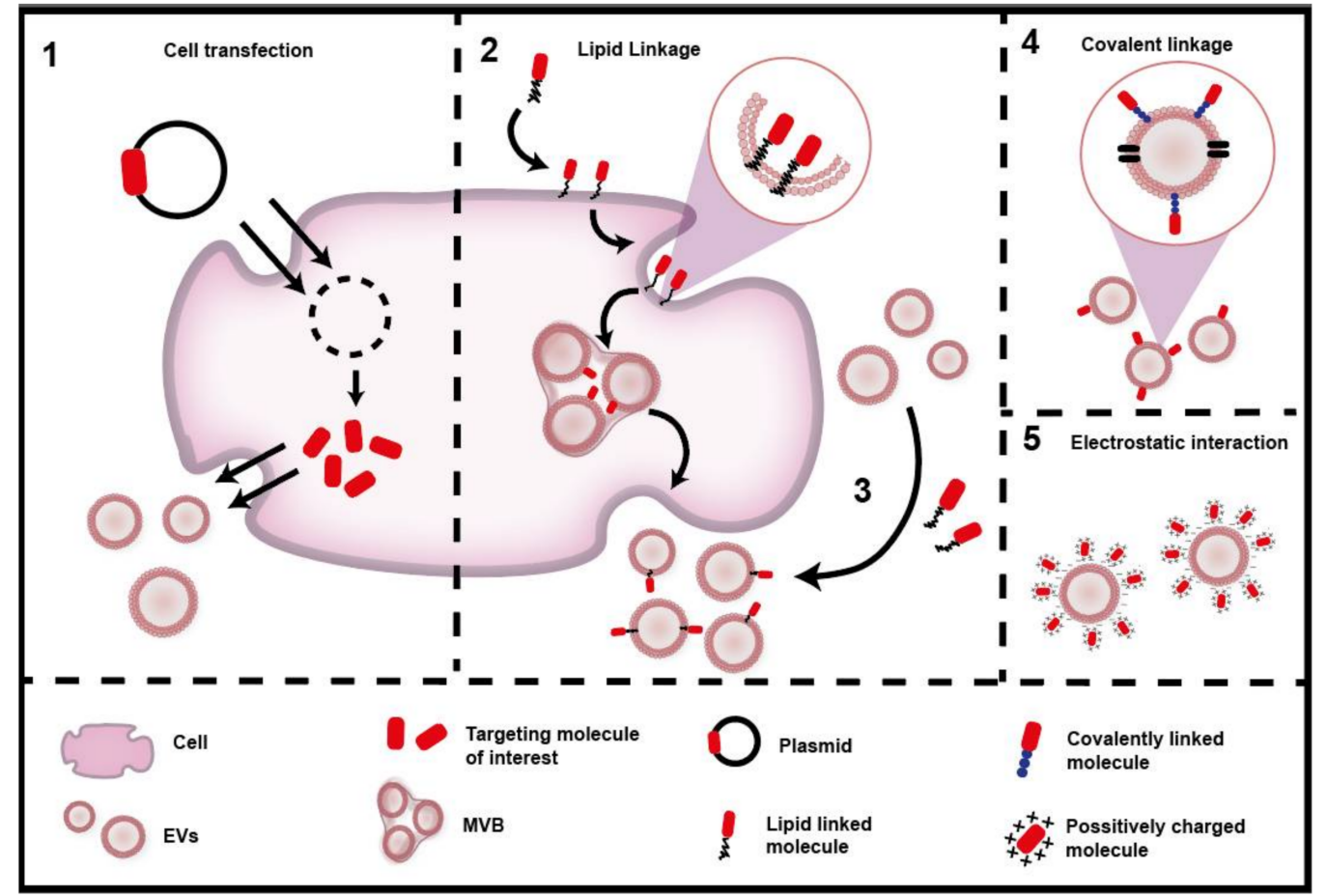

Figure 4. Engineering targeting strategies. EV targeting can be manipulated by adding targeting ligands using different strategies. (1) Transfection of the cell with a plasmid to generate the target protein within the cell and thereby facilitate secretion in EVs. (2) Modification of the targeting molecule with a lipid that can be anchored to the membrane of the cells and then indirectly secreted on EVs or (3) by directly adding lipid-linked molecules to the surface of EVs. (4) Covalently linking the targeting agent into the surface of EVs. (5) Using a cationic compound to promote electrostatic interactions with the EVs.

Covalent linkage: In this case, the desired targeting molecule is attached to the EV surface by a chemical reaction. The amine/carboxylic groups present in the membrane of the EVs can be functionalized using the EDC/NHS reaction giving rise to stable covalent amide bonds. This strategy can be combined with click chemistry, which permits incorporating complex ligands in a fast reaction with high specificity $[12,14,119]$. 
Table 2. Examples of EVs engineered strategies to improve targeting towards specific cells.

\begin{tabular}{|c|c|c|c|c|}
\hline Method & Isolated from & Engineered with & Targeting to & Reference \\
\hline \multirow{2}{*}{ Covalent linkage } & $\begin{array}{l}\text { Bone marrow } \\
\text { MSCs }\end{array}$ & $\alpha v \beta 3$ integrin targeting peptide $c($ RGDyK) & Ischemic brain & [12] \\
\hline & $\begin{array}{l}\text { Macrophages } \\
\text { RAW } 264.7\end{array}$ & neuropilin-1-targeted peptide (RGERPPR) & Glioma & [14] \\
\hline \multirow{2}{*}{ Direct lipid linkage } & Macrophages RAW 264.7 & $\begin{array}{l}\text { Sigma receptor targeting ligand } \\
\text { z(aminoethylanisamide, AA })\end{array}$ & Pulmonary metastasis & [125] \\
\hline & Cardiosphere-derived cells & cardiac homing peptide CSTSMLKAC (CHP) & Myocardial infarction & [121] \\
\hline \multirow{2}{*}{ Indirect lipid linkage } & $\begin{array}{l}\text { Leukemia cells } \\
\text { K562 }\end{array}$ & $\alpha \mathrm{v} \beta 3$ integrin targeting peptide $\mathrm{c}(\mathrm{RGDyK})$ & Angiogenic blood vessel & [122] \\
\hline & $\begin{array}{l}\text { Umbilical vein endothelial } \\
\text { cells (HUVECs) }\end{array}$ & Biotin & HepG2 tumors & [126] \\
\hline \multirow{5}{*}{ Transfection } & Immature mouse DCs & $\begin{array}{l}\alpha \mathrm{v} \beta 3 \text { integrin targeting peptide (CRGDKGPDC) } \\
\text { (iRGD) }\end{array}$ & MDA-MB-231 tumors & [123] \\
\hline & $\begin{array}{l}\text { Embryonic kidney cells } \\
\text { (HEK293) }\end{array}$ & IL3 ligand & $\begin{array}{l}\text { Chronic myelogenous } \\
\text { leukemia (CML) }\end{array}$ & [124] \\
\hline & $\begin{array}{l}\text { Bone marrow } \\
\text { DCs }\end{array}$ & $\begin{array}{c}\alpha \mathrm{v} \beta 3 \text { integrin targeting peptide } \\
\text { YTIWMPENPRPGTPCDIFTNSRGKRASNG (RVG) }\end{array}$ & Brain & [28] \\
\hline & $\begin{array}{l}\text { Embryonic kidney cells } \\
\text { (HEK293) }\end{array}$ & cardiac-targeting peptide APWHLSSQYSRT (CTP) & Cardiac tissue & [9] \\
\hline & $\begin{array}{l}\text { Embryonic kidney cells } \\
\text { (HEK293) }\end{array}$ & Epstein-Barr virus protein (gp350) & B cell tropism & [16] \\
\hline Passive adsorption & MSCs & Spermine cationized pullulan & Liver tissue & [120] \\
\hline
\end{tabular}

Electrostatic interaction: This strategy refers to the utilization of positively charged molecules that can be attached to the EVs via electrostatic interactions. This is possible because the EV surface is negatively charged, so this simple method does not require any chemical reactions [120].

Direct lipid linkage: This method involves attaching the targeting ligand to a lipid or lipid-like molecule, which will spontaneously insert into the vesicle surface exposing the targeting compound. An example here is the coupling of a cardiac homing peptide to the neutral phospholipid dioleoylphosphatidylethanolamine (DOPE). This is achieved by conjugating DOPE-NHS with the desired peptide for targeted heart therapy [121].

Indirect lipid linkage: An alternative to the previous method is to incubate the cells with a lipid complex conjugated to polyethylenglycol (PEG) which is incorporated into the membrane and then released on the surface of EVs. Pegylation of EVs is an excellent way to enhance stability, circulation time and allows further functionalization with other molecules to enhance targeting [15]. For example, a DSPE-PEG-RGD complex was incubated with K562 cells for membrane inclusion. The complex was later found on EVs which had increased targeting towards blood vessels [122].

Cell transfection: This is a more complex process, as it involves engineering cells to secrete EVs including the desired targeting molecule. This process is achieved by transfecting genetic material into cells which is then stably or transiently incorporated in the cells to produce the target protein. The effectivity of this strategy was demonstrated by Tian et al. 2014, who engineered cells to express the EV membrane protein Lamp2b fused to an $\alpha \mathrm{v}$ integrin-specific peptide for targeted antitumor therapy [123]. Similar approaches have been studied to target EVs towards chronic leukemia cells [124], brain [28] and cardiac tissue [9].

\subsubsection{Tracking Studies of EVs}

The use of EVs likely represents a key approach to selectively target organs; however, many technological limitations exist that make it difficult to analyze the effects of these vesicles in vivo. In order to exploit the targeting properties of the EVs for multidisciplinary applications, it is necessary to be able to track their uptake and distribution throughout the organism. Currently, several imaging techniques are available in the clinic for diagnostic applications, such as computed tomography (CT), magnetic resonance imaging (MRI), X-ray, ultrasound, positron emission tomography (PET) and single-photon emission computed tomography (SPECT). All of these techniques could potentially be 
used to image EVs with high sensitivity and endow them simultaneously with therapeutic properties to allow theranostic applications as we discuss below and in Figure 5.
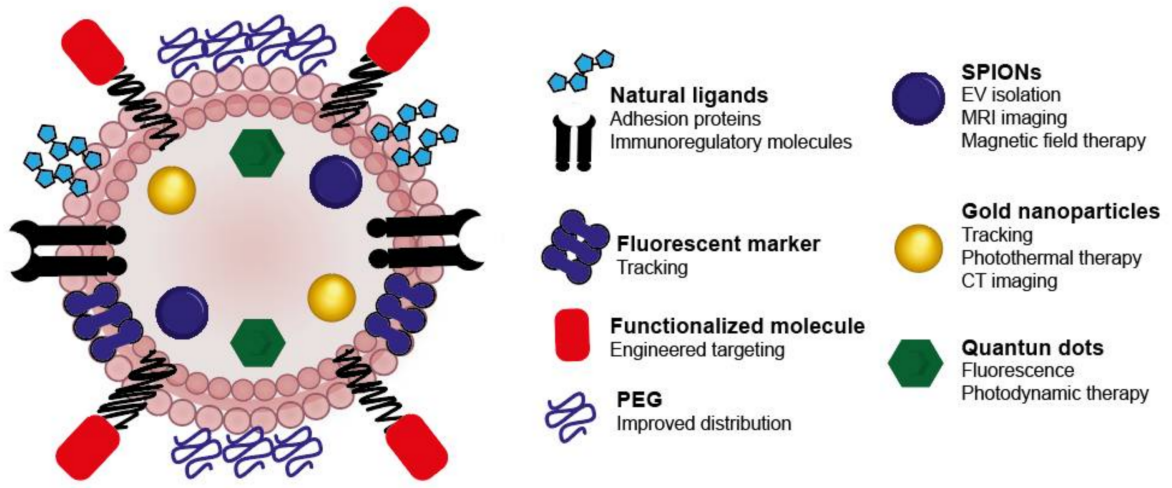

Figure 5. Theranostic EV. Combining the natural properties of EVs with drug loading and targeting strategies leads to multiple therapeutic benefits, such as enhanced uptake/targeting, prolonged circulation time, immunomodulation, tracking and therapy. The utilization of NPs is interesting, as they can add multiple features simultaneously (e.g., tracking and therapy) reducing the requirement of multiple drugs. SPION: superparamagnetic iron oxide nanoparticles; CT: computed tomography; PEG: polyethylenglycol.

Fluorescence is the most common way of EV tracking because of its high versatility. EVs can be labelled simply by incubation with a great variety of lipophilic fluorescent markers that combine different excitation/emission wavelengths. It has been suggested that the lipophilic marker is quickly stabilized in the membrane of the extracellular vesicles. As tissue transparency is attained only using wavelengths above $780 \mathrm{~nm}$ (therapeutic window), near-infrared dyes have become quite popular and are currently the most used for in vivo imaging of EVs. Although tracking fluorescence is a widely used technique for imaging, it is still not a reliable technique for clinical use. The stability and performance of fluorophores are limited by several effects such as scattering, tissue autofluorescence and photobleaching. In addition, they can be easily degraded by oxidation reactions in the organism. Recently, it has been reported that lipophilic fluorescent dyes can be transferred from EVs to other extracellular components, leading to unspecific labelling [69]. Moreover, dyes can spontaneously form micelles which also stain cells, limiting the conclusions that can be drawn concerning uptake and distribution of EVs $[69,127]$. Naturally expressing fluorescent proteins such as GFP/RFP by transfecting cells would result in a more stable labelling. However, these are still limited by their fluorescence in the visible light spectrum which makes them poorly reliable for in vivo analysis [128]. Therefore, novel approaches have been developed to improve EV imaging. As an alternative to the commonly used fluorescence probes, Zhang et al. 2018 proposed indirectly labelling EVs by covalently conjugating membrane phospholipids with fluorescent markers, which permits reducing the non-specific extracellular labelling [129]. By taking advantage of the sulfhydryl groups on the EV surface, maleimide-conjugated Alexa-fluor dyes were covalently added to the EV surface by simple incubation [130]. Protein-based labelling of EVs has also been achieved by using luciferase reporters on cells to produce bioluminescent proteins that are later transferred to the EVs which permit stable real time monitoring [131,132].

Gold nanoparticles are another very interesting class of nanomaterials that can be used for EV tracking because of their high tunability, biocompatibility and unique optical properties related to their surface plasmon resonance $[133,134]$. These properties allow AuNPs to be used for enhancing CT imaging, photoacoustic imaging and photothermal therapy, which is useful for simultaneous imaging and tumor ablation in cancer therapy. These NPs have been effectively incorporated into EVs and used for therapeutic purposes, to analyze the EV sorting pathways in cells, as well as for CT analysis [3,135]. Betzer et al. 2017 incorporated gold nanoparticles into EVs from MSCs and used them 
for in vivo neuroimaging by computer tomography and ex vivo analysis by inductively coupled plasma spectrometry (ICP), which allows quantitative analysis of EV distribution [3]. As direct gold labelling techniques may affect the distribution, we developed a double labelling method to incorporate AuNPs indirectly into EVs by incubating them with cells and combining this with direct fluorescent labelling of the EVs to permit analyzing EV biodistribution by neutron activation analysis, NIR fluorescence, CT imaging and gold-enhanced microscopy imaging. We showed that the indirect gold labelling strategy did not affect biodistribution and were able to identify the presence of AuNP-labelled melanoma EVs in small metastatic foci in the animal lungs [13].

Superparamagnetic iron oxide nanoparticles (SPIONs) are also interesting systems for imaging as they can be used for magnetic resonance imaging. They have the additional advantage that they can be used to facilitate EV isolation using magnets $[40,136]$ and for simultaneous therapy using a magnetic field [40]. These NPs have also been effectively incorporated into EVs and used for in vivo imaging by magnetic particle imaging [79] and MRI $[2,43,137]$. Other authors have encapsulated quantum dots (QDs) into EVs. These strongly fluorescent materials could be useful for variety of fluorescence analysis techniques, because of their enhanced stability and the possibility of using them simultaneously for photodynamic therapy [138].

Combining multiple imaging compounds may represent a workable strategy for multimodal imaging in combination with therapy. Rehman et al. 2018 developed an interesting method to indirectly load gold and Fe nanoclusters into EVs. The authors pre-incubated cells with the salts $\mathrm{HAuCl} 4$ and $\mathrm{FeCl} 2$ to produce the required nanoclusters in cells and then release them as EV cargos [139]. Although the authors did not provide evidence that the EVs retained their biodistribution after the loading, this may represent an interesting strategy to load EVs with multiple NPs for theranostic applications.

\section{The potential Risks and Limitations Associated with the Use of EVs}

\subsection{Therapeutic Risks}

EVs have great potential for the treatment and prevention of several diseases. However, it is important to consider that there are multiple limitations associated with their utilization and little information exists concerning the risk after prolonged exposure to these natural signaling vesicles. Several authors have reported studies that reveal the risk of EVs in cancer, particularly of tumor-derived EVs (TEVs), which have been shown to facilitate drug resistance, tumor progression and metastasis $[20,140,141]$. Some important examples include the role of melanoma EVs in facilitating metastasis by supporting tumor growth, preparing the metastatic niche, inducing vascular leakiness and reprograming of bone marrow cells [141]. Further, TEVs have been reported to promote tumor growth by suppressing NK cell function [142], inducing lymphocyte apoptosis [143] and driving epithelial mesenchymal transition [140]. The presence of a variety of signaling molecules in the EVs is often linked to these effects. For example, the presence of CAV-1 in EVs from breast metastatic cells is associated with enhanced migration and invasion of recipient cells [144] and the EV transfer of MET with melanoma metastasis to the bone marrow [141]. Recent studies also point towards negatives effects in the cardiovascular system. For example, cardiac fibroblast-derived EVs have been shown to activate the angiotensin II receptor type I pathway, which is involved in hypertrophy and heart failure [145]. Moreover, neutrophil EVs have been shown to contribute to vascular inflammation and atherogenesis [146]. There is currently limited information about approaches focusing on modifying EVs to ameliorate these problems without affecting their therapeutic potential. For example, an interesting challenge ahead will be to develop a strategy that permits removing the malignant cargos from TEVs while maintaining their targeting and immunomodulatory properties.

\subsection{Technical Limitations}

In addition to their therapeutic risk, there are several technical challenges that need to be addressed for effective commercialization of EVs as biological drugs. Considering their heterogeneity, 
the preparation of EVs from cell cultures or blood needs to be standardized to obtain reproducible batches with similar biological activity. Good manufacturing guidelines should be developed to obtain products with similar quality. Producing large amounts of EVs is essential for worldwide marketing. Therefore, scaling-up strategies should be developed by using novel isolation methods or improving the limitations of the current ones (e.g., low yield and poor sorting of EV subpopulations). Some authors suggest that for MSCs, a total of 500 million cells will be needed to obtain enough EVs for a given therapeutic intervention. This value was extrapolated from experiments in mice considering that $80 \mu \mathrm{g}$ is approximately the amount of exosomes released from 2 million MSCs in $48 \mathrm{~h}[147,148]$. Achieving this will require improving current manufacturing strategies, such as bioreactor culture platforms, as well as concentration and separation technologies [148]. The stability of the EVs is also an issue as the vesicle content of proteins or RNA can be altered by changes in temperature. Currently, $-80{ }^{\circ} \mathrm{C}$ is the most accepted storage condition to preserve EVs for longer periods of time. However, multiple freeze/thawing cycles of the samples can also alter their vesicular structure and their biological activity [149]. Therefore novel stabilization strategies, such as using buffers or polymers, should be developed as a way to overcome these issues. Finally, the characterization techniques should also be improved in order to determine the molecular composition of each type of $\mathrm{EV}$, standardize their quality and determine the batch-to-batch variability between samples [150]. These procedures will be of particular importance for clinical applications of EVs from external sources (e.g., plants, milk or patient EVs), which are mostly limited by their variability and will greatly benefit from quality standardization. In the future, we may be able to profile the therapeutic properties of EVs and generate easily-scalable synthetic systems that contain specific EV molecules for personalized medicine.

\section{Summary and Future Perspectives}

EVs have shown great potential for the development of multiple drug delivery and vaccination strategies. As natural modulators of cellular communication, EVs provide a unique source of biological information which will depend on their cellular origin and can be exploited for therapeutic or diagnostic approaches. EVs can provide multiple benefits in comparison with other drug delivery systems. Here, we reviewed some of their natural advantages, which include their organ tropism, cardioprotective effects, and antitumoral properties, as well as their ability to modulate inflammation and promote tissue regeneration. These effects could be useful for more personalized medicines in order to increase the effectiveness or reduce the side effects of drugs, for instance by modulating the tumor microenvironment to overcome drug resistance and reducing the cardiotoxicity of chemotherapy. The evidence of cell type-dependent uptake and distribution holds great promise for targeted therapy. Exploiting these properties obliviates the need for functionalization or chemical modifications, thereby facilitating translation to the clinic. Detecting and analyzing EV distribution are important in order to understand their trafficking inside our body and the mechanisms involved as well as to uncover new adhesion molecules that determine their homing selectivity. This information will also help to develop novel synthetic delivery systems with similar homing properties and fewer side effects than EVs that can be produced on an industrial scale. Multimodal imaging of EVs may be achieved by using different types of nanoparticles and fluorophores which, when combined with the targeting abilities of these vesicles, could lead to the development of powerful tools in theranostics. As novel technological approaches arise, we may be able to determine and control the risk associated with EVs after prolonged exposure. Standardization of the isolation of different EV subtypes and upscaling their preparation will be essential to exploit the potential of these very heterogeneous membrane-based structures. In the future, EVs loaded with contrast agents could be used for early diagnosis of diseases, such as cancer, by imaging techniques such as CT and MRI. Further, they may serve as vectors for the selective delivery of drugs to specific parts of the body, thereby reducing side effects and improving patient outcome.

Author Contributions: Conceptualization and investigation, P.L., A.B.C., L.J.C., A.F.G.Q. and M.J.K. Writing, review and editing, P.L., M.J.K. and A.F.G.Q., Supervision and project administration, A.B.C., L.J.C., A.F.G.Q. and M.J.K. All authors have read and agreed to the published version of the manuscript. 
Funding: This project has received funding from the European Union's Horizon 2020 research and innovation program under the Marie Sklodowska Curie grant agreement no. 777682 (CANCER), 734684 (CHARMED), 872391 (CONCRETE), PRISAR2 (872860); ACORN (807281), SIMICA (852985) and by Agencia Nacional de Investigación y Desarrollo (ANID) Chile, grants FONDECYT \#1170925 (AFGQ), FONDAP \#15130011 (AFGQ, MK), Fondecyt 1170929 (MK).

Conflicts of Interest: The authors declare no conflict of interest.

\section{References}

1. Rosenblum, D.; Joshi, N.; Tao, W.; Karp, J.M.; Peer, D. Progress and challenges towards targeted delivery of cancer therapeutics. Nat. Commun. 2018, 9, 1410. [CrossRef] [PubMed]

2. Busato, A.; Bonafede, R.; Bontempi, P.; Scambi, I.; Schiaffino, L.; Benati, D.; Malatesta, M.; Sbarbati, A.; Marzola, P.; Mariotti, R. Labeling and Magnetic Resonance Imaging of Exosomes Isolated from Adipose Stem Cells. Curr. Protoc. Cell Biol. 2017, 75, 3.44.1-3.44.15. [CrossRef] [PubMed]

3. Betzer, O.; Perets, N.; Angel, A.; Motiei, M.; Sadan, T.; Yadid, G.; Offen, D.; Popovtzer, R. In Vivo Neuroimaging of Exosomes Using Gold Nanoparticles. ACS Nano 2017, 11, 10883-10893. [CrossRef] [PubMed]

4. Ju, Z.; Ma, J.; Wang, C.; Yu, J.; Qiao, Y.; Hei, F. Exosomes from iPSCs Delivering siRNA Attenuate Intracellular Adhesion Molecule-1 Expression and Neutrophils Adhesion in Pulmonary Microvascular Endothelial Cells. Inflammation 2017, 40, 486-496. [CrossRef] [PubMed]

5. Jiang, X.C.; Gao, J.Q. Exosomes as novel bio-carriers for gene and drug delivery. Int. J. Pharm. 2017, 521, 167-175. [CrossRef] [PubMed]

6. Haney, M.J.; Klyachko, N.L.; Zhao, Y.; Gupta, R.; Plotnikova, E.G.; He, Z.; Patel, T.; Piroyan, A.; Sokolsky, M.; Kabanov, A.V.; et al. Exosomes as drug delivery vehicles for Parkinson's disease therapy. J. Control. Release 2015, 207, 18-30. [CrossRef] [PubMed]

7. Khan, M.; Nickoloff, E.; Abramova, T.; Johnson, J.; Verma, S.K.; Krishnamurthy, P.; Mackie, A.R.; Vaughan, E.; Garikipati, V.N.; Benedict, C.; et al. Embryonic stem cell-derived exosomes promote endogenous repair mechanisms and enhance cardiac function following myocardial infarction. Circ. Res. 2015, 117, 52-64. [CrossRef]

8. Liu, Q.; Rojas-Canales, D.M.; Divito, S.J.; Shufesky, W.J.; Stolz, D.B.; Erdos, G.; Sullivan, M.L.; Gibson, G.A.; Watkins, S.C.; Larregina, A.T.; et al. Donor dendritic cell-derived exosomes promote allograft-targeting immune response. J. Clin. Investig. 2016, 126, 2805-2820. [CrossRef]

9. Kim, H.; Yun, N.; Mun, D.; Kang, J.Y.; Lee, S.H.; Park, H.; Park, H.; Joung, B. Cardiac-specific delivery by cardiac tissue-targeting peptide-expressing exosomes. Biochem. Biophys. Res. Commun. 2018, 499, 803-808. [CrossRef]

10. Xiao, J.; Pan, Y.; Li, X.H.; Yang, X.Y.; Feng, Y.L.; Tan, H.H.; Jiang, L.; Feng, J.; Yu, X.Y. Cardiac progenitor cell-derived exosomes prevent cardiomyocytes apoptosis through exosomal miR-21 by targeting PDCD4. Cell Death Dis. 2016, 7, e2277. [CrossRef]

11. Munagala, R.; Aqil, F.; Jeyabalan, J.; Gupta, R.C. Bovine milk-derived exosomes for drug delivery. Cancer Lett. 2016, 371, 48-61. [CrossRef] [PubMed]

12. Tian, T.; Zhang, H.X.; He, C.P.; Fan, S.; Zhu, Y.L.; Qi, C.; Huang, N.P.; Xiao, Z.D.; Lu, Z.H.; Tannous, B.A.; et al. Surface functionalized exosomes as targeted drug delivery vehicles for cerebral ischemia therapy. Biomaterials 2018, 150, 137-149. [CrossRef] [PubMed]

13. Lara, P.; Palma-Florez, S.; Salas-Huenuleo, E.; Polakovicova, I.; Guerrero, S.; Lobos-Gonzalez, L.; Campos, A.; Munoz, L.; Jorquera-Cordero, C.; Varas-Godoy, M.; et al. Gold nanoparticle based double-labeling of melanoma extracellular vesicles to determine the specificity of uptake by cells and preferential accumulation in small metastatic lung tumors. J. Nanobiotechnology 2020, 18, 20. [CrossRef] [PubMed]

14. Jia, G.; Han, Y.; An, Y.; Ding, Y.; He, C.; Wang, X.; Tang, Q. NRP-1 targeted and cargo-loaded exosomes facilitate simultaneous imaging and therapy of glioma in vitro and in vivo. Biomaterials 2018, 178, 302-316. [CrossRef]

15. Kooijmans, S.A.A.; Fliervoet, L.A.L.; van der Meel, R.; Fens, M.; Heijnen, H.F.G.; van Bergen En Henegouwen, P.M.P.; Vader, P.; Schiffelers, R.M. PEGylated and targeted extracellular vesicles display enhanced cell specificity and circulation time. J. Control. Release 2016, 224, 77-85. [CrossRef] 
16. Ruiss, R.; Jochum, S.; Mocikat, R.; Hammerschmidt, W.; Zeidler, R. EBV-gp350 confers B-cell tropism to tailored exosomes and is a neo-antigen in normal and malignant B cells-A new option for the treatment of B-CLL. PLoS ONE 2011, 6, e25294. [CrossRef]

17. Thery, C.; Witwer, K.W.; Aikawa, E.; Alcaraz, M.J.; Anderson, J.D.; Andriantsitohaina, R.; Antoniou, A.; Arab, T.; Archer, F.; Atkin-Smith, G.K.; et al. Minimal information for studies of extracellular vesicles 2018 (MISEV2018): A position statement of the International Society for Extracellular Vesicles and update of the MISEV2014 guidelines. J. Extracell. Vesicles 2018, 7, 1535750. [CrossRef]

18. O'Neill, H.C.; Quah, B.J. Exosomes secreted by bacterially infected macrophages are proinflammatory. Sci. Signal. 2008, 1, pe8. [CrossRef]

19. Syn, N.L.; Wang, L.; Chow, E.K.; Lim, C.T.; Goh, B.C. Exosomes in Cancer Nanomedicine and Immunotherapy: Prospects and Challenges. Trends Biotechnol. 2017, 35, 665-676. [CrossRef]

20. Abak, A.; Abhari, A.; Rahimzadeh, S. Exosomes in cancer: Small vesicular transporters for cancer progression and metastasis, biomarkers in cancer therapeutics. PeerJ 2018, 6, e4763. [CrossRef]

21. Masaoutis, C.; Mihailidou, C.; Tsourouflis, G.; Theocharis, S. Exosomes in lung cancer diagnosis and treatment. From the translating research into future clinical practice. Biochimie 2018, 151, 27-36. [CrossRef] [PubMed]

22. Sheller-Miller, S.; Lei, J.; Saade, G.; Salomon, C.; Burd, I.; Menon, R. Feto-Maternal Trafficking of Exosomes in Murine Pregnancy Models. Front. Pharmacol. 2016, 7, 432. [CrossRef]

23. Willms, E.; Johansson, H.J.; Mager, I.; Lee, Y.; Blomberg, K.E.; Sadik, M.; Alaarg, A.; Smith, C.I.; Lehtio, J.; El Andaloussi, S.; et al. Cells release subpopulations of exosomes with distinct molecular and biological properties. Sci. Rep. 2016, 6, 22519. [CrossRef]

24. Vader, P.; Breakefield, X.O.; Wood, M.J. Extracellular vesicles: Emerging targets for cancer therapy. Trends Mol. Med. 2014, 20, 385-393. [CrossRef] [PubMed]

25. Shahabipour, F.; Barati, N.; Johnston, T.P.; Derosa, G.; Maffioli, P.; Sahebkar, A. Exosomes: Nanoparticulate tools for RNA interference and drug delivery. J. Cell. Physiol. 2017, 232, 1660-1668. [CrossRef] [PubMed]

26. Cai, Q.; Zhu, A.; Gong, L. Exosomes of glioma cells deliver miR-148a to promote proliferation and metastasis of glioblastoma via targeting CADM1. Bull. Cancer 2018, 105, 643-651. [CrossRef]

27. Buschow, S.I.; van Balkom, B.W.; Aalberts, M.; Heck, A.J.; Wauben, M.; Stoorvogel, W. MHC class II-associated proteins in B-cell exosomes and potential functional implications for exosome biogenesis. Immunol. Cell Biol. 2010, 88, 851-856. [CrossRef] [PubMed]

28. Alvarez-Erviti, L.; Seow, Y.; Yin, H.; Betts, C.; Lakhal, S.; Wood, M.J. Delivery of siRNA to the mouse brain by systemic injection of targeted exosomes. Nat. Biotechnol. 2011, 29, 341-345. [CrossRef]

29. Batrakova, E.V.; Kim, M.S. Using exosomes, naturally-equipped nanocarriers, for drug delivery. J. Control. Release 2015, 219, 396-405. [CrossRef]

30. Valadi, H.; Ekstrom, K.; Bossios, A.; Sjostrand, M.; Lee, J.J.; Lotvall, J.O. Exosome-mediated transfer of mRNAs and microRNAs is a novel mechanism of genetic exchange between cells. Nat. Cell Biol. 2007, 9, 654-659. [CrossRef]

31. Lee, Y.; El Andaloussi, S.; Wood, M.J. Exosomes and microvesicles: Extracellular vesicles for genetic information transfer and gene therapy. Hum. Mol. Genet. 2012, 21, R125-R134. [CrossRef] [PubMed]

32. McKelvey, K.J.; Powell, K.L.; Ashton, A.W.; Morris, J.M.; McCracken, S.A. Exosomes: Mechanisms of Uptake. J. Circ. Biomark. 2015, 4, 7. [CrossRef] [PubMed]

33. Wu, X.; Liu, Z.; Hu, L.; Gu, W.; Zhu, L. Exosomes derived from endothelial progenitor cells ameliorate acute lung injury by transferring miR-126. Exp. Cell Res. 2018, 370, 13-23. [CrossRef] [PubMed]

34. Huang, B.; Lu, J.; Ding, C.; Zou, Q.; Wang, W.; Li, H. Exosomes derived from human adipose mesenchymal stem cells improve ovary function of premature ovarian insufficiency by targeting SMAD. Stem Cell Res. Ther. 2018, 9, 216. [CrossRef] [PubMed]

35. Lobb, R.J.; van Amerongen, R.; Wiegmans, A.; Ham, S.; Larsen, J.E.; Moller, A. Exosomes derived from mesenchymal non-small cell lung cancer cells promote chemoresistance. Int. J. Cancer 2017, 141, 614-620. [CrossRef] [PubMed]

36. Ludwig, N.; Yerneni, S.S.; Razzo, B.M.; Whiteside, T.L. Exosomes from HNSCC Promote Angiogenesis through Reprogramming of Endothelial Cells. Mol. Cancer Res. 2018. [CrossRef]

37. Wiklander, O.P.; Nordin, J.Z.; O’Loughlin, A.; Gustafsson, Y.; Corso, G.; Mager, I.; Vader, P.; Lee, Y.; Sork, H.; Seow, Y.; et al. Extracellular vesicle in vivo biodistribution is determined by cell source, route of administration and targeting. J. Extracell. Vesicles 2015, 4, 26316. [CrossRef] 
38. Ju, S.; Mu, J.; Dokland, T.; Zhuang, X.; Wang, Q.; Jiang, H.; Xiang, X.; Deng, Z.B.; Wang, B.; Zhang, L.; et al. Grape exosome-like nanoparticles induce intestinal stem cells and protect mice from DSS-induced colitis. Mol. Ther. 2013, 21, 1345-1357. [CrossRef]

39. Grapp, M.; Wrede, A.; Schweizer, M.; Huwel, S.; Galla, H.J.; Snaidero, N.; Simons, M.; Buckers, J.; Low, P.S.; Urlaub, H.; et al. Choroid plexus transcytosis and exosome shuttling deliver folate into brain parenchyma. Nat. Commun. 2013, 4, 2123. [CrossRef]

40. Qi, H.; Liu, C.; Long, L.; Ren, Y.; Zhang, S.; Chang, X.; Qian, X.; Jia, H.; Zhao, J.; Sun, J.; et al. Blood Exosomes Endowed with Magnetic and Targeting Properties for Cancer Therapy. ACS Nano 2016, 10, 3323-3333. [CrossRef]

41. Lynch, S.; Santos, S.G.; Campbell, E.C.; Nimmo, A.M.; Botting, C.; Prescott, A.; Antoniou, A.N.; Powis, S.J. Novel MHC class I structures on exosomes. J. Immunol. 2009, 183, 1884-1891. [CrossRef] [PubMed]

42. Kamerkar, S.; LeBleu, V.S.; Sugimoto, H.; Yang, S.; Ruivo, C.F.; Melo, S.A.; Lee, J.J.; Kalluri, R. Exosomes facilitate therapeutic targeting of oncogenic KRAS in pancreatic cancer. Nature 2017, 546, 498-503. [CrossRef]

43. Hu, L.; Wickline, S.A.; Hood, J.L. Magnetic resonance imaging of melanoma exosomes in lymph nodes. Magn. Reson. Med. 2015, 74, 266-271. [CrossRef] [PubMed]

44. Johnsen, K.B.; Gudbergsson, J.M.; Skov, M.N.; Christiansen, G.; Gurevich, L.; Moos, T.; Duroux, M. Evaluation of electroporation-induced adverse effects on adipose-derived stem cell exosomes. Cytotechnology 2016, 68, 2125-2138. [CrossRef]

45. Kooijmans, S.A.A.; Stremersch, S.; Braeckmans, K.; de Smedt, S.C.; Hendrix, A.; Wood, M.J.A.; Schiffelers, R.M.; Raemdonck, K.; Vader, P. Electroporation-induced siRNA precipitation obscures the efficiency of siRNA loading into extracellular vesicles. J. Control. Release 2013, 172, 229-238. [CrossRef] [PubMed]

46. Sun, D.; Zhuang, X.; Xiang, X.; Liu, Y.; Zhang, S.; Liu, C.; Barnes, S.; Grizzle, W.; Miller, D.; Zhang, H.G. A novel nanoparticle drug delivery system: The anti-inflammatory activity of curcumin is enhanced when encapsulated in exosomes. Mol. Ther. 2010, 18, 1606-1614. [CrossRef] [PubMed]

47. Sukreet, S.; Silva, B.V.R.E.; Adamec, J.; Cui, J.; Zempleni, J. Sonication and Short-term Incubation Alter the Content of Bovine Milk Exosome Cargos and Exosome Bioavailability (OR26-08-19). Curr. Dev. Nutr. 2019, 3, 696-700. [CrossRef]

48. Katakowski, M.; Buller, B.; Zheng, X.; Lu, Y.; Rogers, T.; Osobamiro, O.; Shu, W.; Jiang, F.; Chopp, M. Exosomes from marrow stromal cells expressing miR-146b inhibit glioma growth. Cancer Lett. 2013, 335, 201-204. [CrossRef]

49. Ohno, S.; Takanashi, M.; Sudo, K.; Ueda, S.; Ishikawa, A.; Matsuyama, N.; Fujita, K.; Mizutani, T.; Ohgi, T.; Ochiya, T.; et al. Systemically injected exosomes targeted to EGFR deliver antitumor microRNA to breast cancer cells. Mol. Ther. 2013, 21, 185-191. [CrossRef]

50. Pascucci, L.; Cocce, V.; Bonomi, A.; Ami, D.; Ceccarelli, P.; Ciusani, E.; Vigano, L.; Locatelli, A.; Sisto, F.; Doglia, S.M.; et al. Paclitaxel is incorporated by mesenchymal stromal cells and released in exosomes that inhibit in vitro tumor growth: A new approach for drug delivery. J. Control. Release 2014, 192, 262-270. [CrossRef]

51. Toribio, V.; Morales, S.; López-Martín, S.; Cardeñes, B.; Cabañas, C.; Yáñez-Mó, M. Development of a quantitative method to measure EV uptake. Sci. Rep. 2019, 9, 10522. [CrossRef] [PubMed]

52. Feng, D.; Zhao, W.L.; Ye, Y.Y.; Bai, X.C.; Liu, R.Q.; Chang, L.F.; Zhou, Q.; Sui, S.F. Cellular internalization of exosomes occurs through phagocytosis. Traffic 2010, 11, 675-687. [CrossRef] [PubMed]

53. Fitzner, D.; Schnaars, M.; van Rossum, D.; Krishnamoorthy, G.; Dibaj, P.; Bakhti, M.; Regen, T.; Hanisch, U.K.; Simons, M. Selective transfer of exosomes from oligodendrocytes to microglia by macropinocytosis. J. Cell Sci. 2011, 124, 447-458. [CrossRef] [PubMed]

54. Morelli, A.E.; Larregina, A.T.; Shufesky, W.J.; Sullivan, M.L.; Stolz, D.B.; Papworth, G.D.; Zahorchak, A.F.; Logar, A.J.; Wang, Z.; Watkins, S.C.; et al. Endocytosis, intracellular sorting, and processing of exosomes by dendritic cells. Blood 2004, 104, 3257-3266. [CrossRef]

55. Tian, T.; Zhu, Y.L.; Hu, F.H.; Wang, Y.Y.; Huang, N.P.; Xiao, Z.D. Dynamics of exosome internalization and trafficking. J. Cell. Physiol. 2013, 228, 1487-1495. [CrossRef]

56. Mulcahy, L.A.; Pink, R.C.; Carter, D.R. Routes and mechanisms of extracellular vesicle uptake. J. Extracell. Vesicles 2014, 3, 24641. [CrossRef] 
57. Smyth, T.J.; Redzic, J.S.; Graner, M.W.; Anchordoquy, T.J. Examination of the specificity of tumor cell derived exosomes with tumor cells in vitro. Biochim. Biophys. Acta 2014, 1838, 2954-2965. [CrossRef]

58. Zwi-Dantsis, L.; Winter, C.W.; Kauscher, U.; Ferrini, A.; Wang, B.; Whittaker, T.E.; Hood, S.R.; Terracciano, C.M.; Stevens, M.M. Highly purified extracellular vesicles from human cardiomyocytes demonstrate preferential uptake by human endothelial cells. Nanoscale 2020, 12, 19844-19854. [CrossRef]

59. Escrevente, C.; Keller, S.; Altevogt, P.; Costa, J. Interaction and uptake of exosomes by ovarian cancer cells. BMC Cancer 2011, 11, 108. [CrossRef]

60. Matsumoto, A.; Takahashi, Y.; Nishikawa, M.; Sano, K.; Morishita, M.; Charoenviriyakul, C.; Saji, H.; Takakura, Y. Accelerated growth of B16BL6 tumor in mice through efficient uptake of their own exosomes by B16BL6 cells. Cancer Sci. 2017, 108, 1803-1810. [CrossRef]

61. Franzen, C.A.; Simms, P.E.; Van Huis, A.F.; Foreman, K.E.; Kuo, P.C.; Gupta, G.N. Characterization of uptake and internalization of exosomes by bladder cancer cells. BioMed Res. Int. 2014, 2014, 619829. [CrossRef] [PubMed]

62. Sancho-Albero, M.; Navascues, N.; Mendoza, G.; Sebastian, V.; Arruebo, M.; Martin-Duque, P.; Santamaria, J. Exosome origin determines cell targeting and the transfer of therapeutic nanoparticles towards target cells. J. Nanobiotechnol. 2019, 17, 16. [CrossRef] [PubMed]

63. Chivet, M.; Javalet, C.; Laulagnier, K.; Blot, B.; Hemming, F.J.; Sadoul, R. Exosomes secreted by cortical neurons upon glutamatergic synapse activation specifically interact with neurons. J. Extracell. Vesicles 2014, 3, 24722. [CrossRef] [PubMed]

64. Kim, S.M.; Yang, Y.; Oh, S.J.; Hong, Y.; Seo, M.; Jang, M. Cancer-derived exosomes as a delivery platform of CRISPR/Cas9 confer cancer cell tropism-dependent targeting. J. Control. Release 2017, 266, 8-16. [CrossRef] [PubMed]

65. Rana, S.; Yue, S.; Stadel, D.; Zoller, M. Toward tailored exosomes: The exosomal tetraspanin web contributes to target cell selection. Int. J. Biochem. Cell Biol. 2012, 44, 1574-1584. [CrossRef]

66. Segura, E.; Nicco, C.; Lombard, B.; Veron, P.; Raposo, G.; Batteux, F.; Amigorena, S.; Thery, C. ICAM-1 on exosomes from mature dendritic cells is critical for efficient naive T-cell priming. Blood 2005, 106, 216-223. [CrossRef] [PubMed]

67. Williams, C.; Pazos, R.; Royo, F.; González, E.; Roura-Ferrer, M.; Martinez, A.; Gamiz, J.; Reichardt, N.-C.; Falcón-Pérez, J.M. Assessing the role of surface glycans of extracellular vesicles on cellular uptake. Sci. Rep. 2019, 9, 11920. [CrossRef]

68. Carobolante, G.; Mantaj, J.; Ferrari, E.; Vllasaliu, D. Cow Milk and Intestinal Epithelial Cell-derived Extracellular Vesicles as Systems for Enhancing Oral Drug Delivery. Pharmaceutics 2020, 12, 226. [CrossRef]

69. Takov, K.; Yellon, D.M.; Davidson, S.M. Confounding factors in vesicle uptake studies using fluorescent lipophilic membrane dyes. J. Extracell. Vesicles 2017, 6, 1388731. [CrossRef]

70. Matsumoto, A.; Takahashi, Y.; Chang, H.-Y.; Wu, Y.-W.; Yamamoto, A.; Ishihama, Y.; Takakura, Y. Blood concentrations of small extracellular vesicles are determined by a balance between abundant secretion and rapid clearance. J. Extracell. Vesicles 2019, 9, 1696517. [CrossRef]

71. Yang, T.; Martin, P.; Fogarty, B.; Brown, A.; Schurman, K.; Phipps, R.; Yin, V.P.; Lockman, P.; Bai, S. Exosome Delivered Anticancer Drugs Across the Blood-Brain Barrier for Brain Cancer Therapy in Danio Rerio. Pharm. Res. 2015, 32, 2003-2014. [CrossRef] [PubMed]

72. Grange, C.; Tapparo, M.; Bruno, S.; Chatterjee, D.; Quesenberry, P.J.; Tetta, C.; Camussi, G. Biodistribution of mesenchymal stem cell-derived extracellular vesicles in a model of acute kidney injury monitored by optical imaging. Int. J. Mol. Med. 2014, 33, 1055-1063. [CrossRef]

73. Bartolome, R.A.; Torres, S.; de Val, S.I.; Escudero-Paniagua, B.; Calvino, E.; Teixido, J.; Casal, J.I. VE-cadherin RGD motifs promote metastasis and constitute a potential therapeutic target in melanoma and breast cancers. Oncotarget 2017, 8, 215-227. [CrossRef]

74. Huang, R.; Rofstad, E.K. Integrins as therapeutic targets in the organ-specific metastasis of human malignant melanoma. J. Exp. Clin. Cancer Res. 2018, 37, 92. [CrossRef] [PubMed]

75. Hoshino, A.; Costa-Silva, B.; Shen, T.L.; Rodrigues, G.; Hashimoto, A.; Tesic Mark, M.; Molina, H.; Kohsaka, S.; Di Giannatale, A.; Ceder, S.; et al. Tumour exosome integrins determine organotropic metastasis. Nature 2015, 527, 329-335. [CrossRef] 
76. Charoenviriyakul, C.; Takahashi, Y.; Morishita, M.; Matsumoto, A.; Nishikawa, M.; Takakura, Y. Cell type-specific and common characteristics of exosomes derived from mouse cell lines: Yield, physicochemical properties, and pharmacokinetics. Eur. J. Pharm. Sci. 2017, 96, 316-322. [CrossRef]

77. Gomzikova, M.; Kletukhina, S.; Kurbangaleeva, S.; Rizvanov, A. Evaluation of Cytochalasin B-Induced Membrane Vesicles Fusion Specificity with Target Cells. BioMed Res. Int. 2018, 2018, 7053623. [CrossRef] [PubMed]

78. Lankford, K.L.; Arroyo, E.J.; Nazimek, K.; Bryniarski, K.; Askenase, P.W.; Kocsis, J.D. Intravenously delivered mesenchymal stem cell-derived exosomes target M2-type macrophages in the injured spinal cord. PLoS ONE 2018, 13, e0190358. [CrossRef] [PubMed]

79. Jung, K.O.; Jo, H.; Yu, J.H.; Gambhir, S.S.; Pratx, G. Development and MPI tracking of novel hypoxia-targeted theranostic exosomes. Biomaterials 2018, 177, 139-148. [CrossRef]

80. Osawa, S.; Kurachi, M.; Yamamoto, H.; Yoshimoto, Y.; Ishizaki, Y. Fibronectin on extracellular vesicles from microvascular endothelial cells is involved in the vesicle uptake into oligodendrocyte precursor cells. Biochem. Biophys. Res. Commun. 2017, 488, 232-238. [CrossRef]

81. Wolfers, J.; Lozier, A.; Raposo, G.; Regnault, A.; Théry, C.; Masurier, C.; Flament, C.; Pouzieux, S.; Faure, F.; Tursz, T.; et al. Tumor-derived exosomes are a source of shared tumor rejection antigens for CTL cross-priming. Nat. Med. 2001, 7, 297-303. [CrossRef] [PubMed]

82. Dai, S.; Wei, D.; Wu, Z.; Zhou, X.; Wei, X.; Huang, H.; Li, G. Phase I Clinical Trial of Autologous Ascites-derived Exosomes Combined With GM-CSF for Colorectal Cancer. Mol. Ther. 2008, 16, 782-790. [CrossRef] [PubMed]

83. Xiao, L.; Erb, U.; Zhao, K.; Hackert, T.; Zoller, M. Efficacy of vaccination with tumor-exosome loaded dendritic cells combined with cytotoxic drug treatment in pancreatic cancer. Oncoimmunology 2017, 6, e1319044. [CrossRef] [PubMed]

84. Gu, X.; Erb, U.; Buchler, M.W.; Zoller, M. Improved vaccine efficacy of tumor exosome compared to tumor lysate loaded dendritic cells in mice. Int. J. Cancer 2015, 136, E74-E84. [CrossRef] [PubMed]

85. Besse, B.; Charrier, M.; Lapierre, V.; Dansin, E.; Lantz, O.; Planchard, D.; Le Chevalier, T.; Livartoski, A.; Barlesi, F.; Laplanche, A.; et al. Dendritic cell-derived exosomes as maintenance immunotherapy after first line chemotherapy in NSCLC. Oncoimmunology 2016, 5, e1071008. [CrossRef] [PubMed]

86. Pitt, J.M.; Andre, F.; Amigorena, S.; Soria, J.C.; Eggermont, A.; Kroemer, G.; Zitvogel, L. Dendritic cell-derived exosomes for cancer therapy. J. Clin. Investig. 2016, 126, 1224-1232. [CrossRef] [PubMed]

87. Wu, C.-H.; Li, J.; Li, L.; Sun, J.; Fabbri, M.; Wayne, A.S.; Seeger, R.C.; Jong, A.Y. Extracellular vesicles derived from natural killer cells use multiple cytotoxic proteins and killing mechanisms to target cancer cells. J. Extracell. Vesicles 2019, 8, 1588538. [CrossRef] [PubMed]

88. Cheng, L.; Wang, Y.; Huang, L. Exosomes from M1-Polarized Macrophages Potentiate the Cancer Vaccine by Creating a Pro-inflammatory Microenvironment in the Lymph Node. Mol. Ther. 2017, 25, 1665-1675. [CrossRef]

89. Wang, P.; Wang, H.; Huang, Q.; Peng, C.; Yao, L.; Chen, H.; Qiu, Z.; Wu, Y.; Wang, L.; Chen, W. Exosomes from M1-Polarized Macrophages Enhance Paclitaxel Antitumor Activity by Activating Macrophages-Mediated Inflammation. Theranostics 2019, 9, 1714-1727. [CrossRef]

90. Scanu, A.; Molnarfi, N.; Brandt, K.J.; Gruaz, L.; Dayer, J.-M.; Burger, D. Stimulated T cells generate microparticles, which mimic cellular contact activation of human monocytes: Differential regulation of pro-and anti-inflammatory cytokine production by high-density lipoproteins. J. Leukoc. Biol. 2008, 83, 921-927. [CrossRef]

91. Dalli, J.; Norling, L.V.; Renshaw, D.; Cooper, D.; Leung, K.-Y.; Perretti, M. Annexin 1 mediates the rapid anti-inflammatory effects of neutrophil-derived microparticles. Blood 2008, 112, 2512-2519. [CrossRef] [PubMed]

92. Sadallah, S.; Eken, C.; Martin, P.J.; Schifferli, J.A. Microparticles (Ectosomes) Shed by Stored Human Platelets Downregulate Macrophages and Modify the Development of Dendritic Cells. J. Immunol. 2011, 186, 6543-6552. [CrossRef] [PubMed]

93. Dinkla, S.; van Cranenbroek, B.; van der Heijden, W.A.; He, X.; Wallbrecher, R.; Dumitriu, I.E.; van der Ven, A.J.; Bosman, G.J.C.G.M.; Koenen, H.J.P.M.; Joosten, I. Platelet microparticles inhibit IL-17 production by regulatory T cells through P-selectin. Blood 2016, 127, 1976-1986. [CrossRef] [PubMed] 
94. Jansen, F.; Yang, X.; Baumann, K.; Przybilla, D.; Schmitz, T.; Flender, A.; Paul, K.; Alhusseiny, A.; Nickenig, G.; Werner, N. Endothelial microparticles reduce ICAM-1 expression in a microRNA-222-dependent mechanism. J. Cell. Mol. Med. 2015, 19, 2202-2214. [CrossRef] [PubMed] 
95. Soriano, A.O.; Jy, W.; Chirinos, J.A.; Valdivia, M.A.; Velasquez, H.S.; Jimenez, J.J.; Horstman, L.L.; Kett, D.H.; Schein, R.M.H.; Ahn, Y.S. Levels of endothelial and platelet microparticles and their interactions with leukocytes negatively correlate with organ dysfunction and predict mortality in severe sepsis. Crit. Care Med. 2005, 33, 2540-2546. [CrossRef] [PubMed]

96. Cosenza, S.; Toupet, K.; Maumus, M.; Luz-Crawford, P.; Blanc-Brude, O.; Jorgensen, C.; Noël, D. Mesenchymal stem cells-derived exosomes are more immunosuppressive than microparticles in inflammatory arthritis. Theranostics 2018, 8, 1399-1410. [CrossRef]

97. Bhatnagar, S.; Schorey, J.S. Exosomes released from infected macrophages contain Mycobacterium avium glycopeptidolipids and are proinflammatory. J. Biol. Chem. 2007, 282, 25779-25789. [CrossRef]

98. Zhang, Y.; Kim, M.S.; Jia, B.; Yan, J.; Zuniga-Hertz, J.P.; Han, C.; Cai, D. Author Correction: Hypothalamic stem cells control ageing speed partly through exosomal miRNAs. Nature 2018, 560, E33. [CrossRef]

99. Prattichizzo, F.; Micolucci, L.; Cricca, M.; De Carolis, S.; Mensà, E.; Ceriello, A.; Procopio, A.D.; Bonafè, M.; Olivieri, F. Exosome-based immunomodulation during aging: A nano-perspective on inflamm-aging. Mech. Ageing Dev. 2017, 168, 44-53. [CrossRef]

100. Wang, Z.; Lieberman, P.M. The crosstalk of telomere dysfunction and inflammation through cell-free TERRA containing exosomes. RNA Biol. 2016, 13, 690-695. [CrossRef]

101. Mitsuhashi, M.; Taub, D.D.; Kapogiannis, D.; Eitan, E.; Zukley, L.; Mattson, M.P.; Ferrucci, L.; Schwartz, J.B.; Goetzl, E.J. Aging enhances release of exosomal cytokine mRNAs by A $\beta 1-42$-stimulated macrophages. FASEB J. Off. Publ. Fed. Am. Soc. Exp. Biol. 2013, 27, 5141-5150. [CrossRef]

102. Doeppner, T.R.; Herz, J.; Gorgens, A.; Schlechter, J.; Ludwig, A.K.; Radtke, S.; de Miroschedji, K.; Horn, P.A.; Giebel, B.; Hermann, D.M. Extracellular Vesicles Improve Post-Stroke Neuroregeneration and Prevent Postischemic Immunosuppression. Stem Cells Transl. Med. 2015, 4, 1131-1143. [CrossRef] [PubMed]

103. Nakamura, Y.; Miyaki, S.; Ishitobi, H.; Matsuyama, S.; Nakasa, T.; Kamei, N.; Akimoto, T.; Higashi, Y.; Ochi, M. Mesenchymal-stem-cell-derived exosomes accelerate skeletal muscle regeneration. FEBS Lett. 2015, 589, 1257-1265. [CrossRef] [PubMed]

104. Tan, C.Y.; Lai, R.C.; Wong, W.; Dan, Y.Y.; Lim, S.K.; Ho, H.K. Mesenchymal stem cell-derived exosomes promote hepatic regeneration in drug-induced liver injury models. Stem Cell Res. Ther. 2014, 5, 76. [CrossRef] [PubMed]

105. Hristov, M.; Erl, W.; Linder, S.; Weber, P.C. Apoptotic bodies from endothelial cells enhance the number and initiate the differentiation of human endothelial progenitor cells in vitro. Blood 2004, 104, 2761-2766. [CrossRef] [PubMed]

106. Lopez-Leal, R.; Court, F.A. Schwann Cell Exosomes Mediate Neuron-Glia Communication and Enhance Axonal Regeneration. Cell. Mol. Neurobiol. 2016, 36, 429-436. [CrossRef]

107. Barile, L.; Lionetti, V.; Cervio, E.; Matteucci, M.; Gherghiceanu, M.; Popescu, L.M.; Torre, T.; Siclari, F.; Moccetti, T.; Vassalli, G. Extracellular vesicles from human cardiac progenitor cells inhibit cardiomyocyte apoptosis and improve cardiac function after myocardial infarction. Cardiovasc. Res. 2014, 103, 530-541. [CrossRef]

108. Lai, R.C.; Arslan, F.; Lee, M.M.; Sze, N.S.; Choo, A.; Chen, T.S.; Salto-Tellez, M.; Timmers, L.; Lee, C.N.; El Oakley, R.M.; et al. Exosome secreted by MSC reduces myocardial ischemia/reperfusion injury. Stem Cell Res. 2010, 4, 214-222. [CrossRef]

109. Gatti, S.; Bruno, S.; Deregibus, M.C.; Sordi, A.; Cantaluppi, V.; Tetta, C.; Camussi, G. Microvesicles derived from human adult mesenchymal stem cells protect against ischaemia-reperfusion-induced acute and chronic kidney injury. Nephrol. Dial. Transplant. 2011, 26, 1474-1483. [CrossRef]

110. Arslan, F.; Lai, R.C.; Smeets, M.B.; Akeroyd, L.; Choo, A.; Aguor, E.N.; Timmers, L.; van Rijen, H.V.; Doevendans, P.A.; Pasterkamp, G.; et al. Mesenchymal stem cell-derived exosomes increase ATP levels, decrease oxidative stress and activate PI3K/Akt pathway to enhance myocardial viability and prevent adverse remodeling after myocardial ischemia/reperfusion injury. Stem Cell Res. 2013, 10, 301-312. [CrossRef]

111. Bruno, S.; Grange, C.; Deregibus, M.C.; Calogero, R.A.; Saviozzi, S.; Collino, F.; Morando, L.; Busca, A.; Falda, M.; Bussolati, B.; et al. Mesenchymal stem cell-derived microvesicles protect against acute tubular injury. J. Am. Soc. Nephrol. 2009, 20, 1053-1067. [CrossRef]

112. Cao, H.; Qian, H.; Xu, W.; Zhu, W.; Zhang, X.; Chen, Y.; Wang, M.; Yan, Y.; Xie, Y. Mesenchymal stem cells derived from human umbilical cord ameliorate ischemia/reperfusion-induced acute renal failure in rats. Biotechnol. Lett. 2010, 32, 725-732. [CrossRef] 
113. Nordin, J.Z.; Lee, Y.; Vader, P.; Mager, I.; Johansson, H.J.; Heusermann, W.; Wiklander, O.P.; Hallbrink, M.; Seow, Y.; Bultema, J.J.; et al. Ultrafiltration with size-exclusion liquid chromatography for high yield isolation of extracellular vesicles preserving intact biophysical and functional properties. Nanomedicine 2015, 11, 879-883. [CrossRef] [PubMed]

114. Taraboletti, G.; D’Ascenzo, S.; Giusti, I.; Marchetti, D.; Borsotti, P.; Millimaggi, D.; Giavazzi, R.; Pavan, A.; Dolo, V. Bioavailability of VEGF in tumor-shed vesicles depends on vesicle burst induced by acidic $\mathrm{pH}$. Neoplasia 2006, 8, 96-103. [CrossRef] [PubMed]

115. Parolini, I.; Federici, C.; Raggi, C.; Lugini, L.; Palleschi, S.; De Milito, A.; Coscia, C.; Iessi, E.; Logozzi, M.; Molinari, A.; et al. Microenvironmental $\mathrm{pH}$ is a key factor for exosome traffic in tumor cells. J. Biol. Chem. 2009, 284, 34211-34222. [CrossRef] [PubMed]

116. Eguchi, T.; Sogawa, C.; Ono, K.; Matsumoto, M.; Tran, M.T.; Okusha, Y.; Lang, B.J.; Okamoto, K.; Calderwood, S.K. Cell Stress Induced Stressome Release Including Damaged Membrane Vesicles and Extracellular HSP90 by Prostate Cancer Cells. Cells 2020, 9, 755. [CrossRef] [PubMed]

117. de la Mare, J.-A.; Jurgens, T.; Edkins, A.L. Extracellular Hsp90 and TGF $\beta$ regulate adhesion, migration and anchorage independent growth in a paired colon cancer cell line model. BMC Cancer 2017, 17, 202. [CrossRef] [PubMed]

118. Kakazu, E.; Mauer, A.S.; Yin, M.; Malhi, H. Hepatocytes release ceramide-enriched pro-inflammatory extracellular vesicles in an IRE1 $\alpha$-dependent manner. J. Lipid Res. 2016, 57, 233-245. [CrossRef]

119. Smyth, T.; Petrova, K.; Payton, N.M.; Persaud, I.; Redzic, J.S.; Graner, M.W.; Smith-Jones, P.; Anchordoquy, T.J. Surface functionalization of exosomes using click chemistry. Bioconjugate Chem. 2014, 25, 1777-1784. [CrossRef]

120. Tamura, R.; Uemoto, S.; Tabata, Y. Augmented liver targeting of exosomes by surface modification with cationized pullulan. Acta Biomater. 2017, 57, 274-284. [CrossRef]

121. Vandergriff, A.; Huang, K.; Shen, D.; Hu, S.; Hensley, M.T.; Caranasos, T.G.; Qian, L.; Cheng, K. Targeting regenerative exosomes to myocardial infarction using cardiac homing peptide. Theranostics 2018, 8, 1869-1878. [CrossRef] [PubMed]

122. Wang, J.; Li, W.; Lu, Z.; Zhang, L.; Hu, Y.; Li, Q.; Du, W.; Feng, X.; Jia, H.; Liu, B.F. The use of RGD-engineered exosomes for enhanced targeting ability and synergistic therapy toward angiogenesis. Nanoscale 2017, 9, 15598-15605. [CrossRef] [PubMed]

123. Tian, Y.; Li, S.; Song, J.; Ji, T.; Zhu, M.; Anderson, G.J.; Wei, J.; Nie, G. A doxorubicin delivery platform using engineered natural membrane vesicle exosomes for targeted tumor therapy. Biomaterials 2014, 35, 2383-2390. [CrossRef] [PubMed]

124. Bellavia, D.; Raimondo, S.; Calabrese, G.; Forte, S.; Cristaldi, M.; Patinella, A.; Memeo, L.; Manno, M.; Raccosta, S.; Diana, P.; et al. Interleukin 3- receptor targeted exosomes inhibit in vitro and in vivo Chronic Myelogenous Leukemia cell growth. Theranostics 2017, 7, 1333-1345. [CrossRef]

125. Kim, M.S.; Haney, M.J.; Zhao, Y.; Yuan, D.; Deygen, I.; Klyachko, N.L.; Kabanov, A.V.; Batrakova, E.V. Engineering macrophage-derived exosomes for targeted paclitaxel delivery to pulmonary metastases: In vitro and in vivo evaluations. Nanomed. Nanotechnol. Biol. Med. 2018, 14, 195-204. [CrossRef]

126. Wang, J.; Li, W.; Zhang, L.; Ban, L.; Chen, P.; Du, W.; Feng, X.; Liu, B.F. Chemically Edited Exosomes with Dual Ligand Purified by Microfluidic Device for Active Targeted Drug Delivery to Tumor Cells. ACS Appl. Mater. Interfaces 2017, 9, 27441-27452. [CrossRef]

127. Wallace, P.K.; Tario, J.D., Jr.; Fisher, J.L.; Wallace, S.S.; Ernstoff, M.S.; Muirhead, K.A. Tracking antigen-driven responses by flow cytometry: Monitoring proliferation by dye dilution. Cytom. A 2008, 73, 1019-1034. [CrossRef]

128. Chuo, S.T.; Chien, J.C.; Lai, C.P. Imaging extracellular vesicles: Current and emerging methods. J. Biomed. Sci. 2018, 25, 91. [CrossRef]

129. Zhang, P.; Dong, B.; Zeng, E.; Wang, F.; Jiang, Y.; Li, D.; Liu, D. In Vivo Tracking of Multiple Tumor Exosomes Labeled by Phospholipid-Based Bioorthogonal Conjugation. Anal. Chem. 2018, 90, 11273-11279. [CrossRef]

130. Roberts-Dalton, H.D.; Cocks, A.; Falcon-Perez, J.M.; Sayers, E.J.; Webber, J.P.; Watson, P.; Clayton, A.; Jones, A.T. Fluorescence labelling of extracellular vesicles using a novel thiol-based strategy for quantitative analysis of cellular delivery and intracellular traffic. Nanoscale 2017, 9, 13693-13706. [CrossRef] 
131. Takahashi, Y.; Nishikawa, M.; Shinotsuka, H.; Matsui, Y.; Ohara, S.; Imai, T.; Takakura, Y. Visualization and in vivo tracking of the exosomes of murine melanoma B16-BL6 cells in mice after intravenous injection. J. Biotechnol. 2013, 165, 77-84. [CrossRef] [PubMed]

132. Lai, C.P.; Mardini, O.; Ericsson, M.; Prabhakar, S.; Maguire, C.A.; Chen, J.W.; Tannous, B.A.; Breakefield, X.O. Dynamic Biodistribution of Extracellular Vesicles in Vivo Using a Multimodal Imaging Reporter. ACS Nano 2014, 8, 483-494. [CrossRef] [PubMed]

133. Guerrero, A.R.; Hassan, N.; Escobar, C.A.; Albericio, F.; Kogan, M.J.; Araya, E. Gold nanoparticles for photothermally controlled drug release. Nanomedicine 2014, 9, 2023-2039. [CrossRef]

134. Inostroza-Riquelme, M.; Vivanco, A.; Lara, P.; Guerrero, S.; Salas-Huenuleo, E.; Chamorro, A.; Leyton, L.; Bolanos, K.; Araya, E.; Quest, A.F.G.; et al. Encapsulation of Gold Nanostructures and Oil-in-Water Nanocarriers in Microgels with Biomedical Potential. Molecules 2018, 23, 1208. [CrossRef]

135. Davidi, E.S.; Dreifuss, T.; Motiei, M.; Shai, E.; Bragilovski, D.; Lubimov, L.; Kindler, M.J.J.; Popovtzer, A.; Don, J.; Popovtzer, R. Cisplatin-conjugated gold nanoparticles as a theranostic agent for head and neck cancer. Head Neck 2018, 40, 70-78. [CrossRef] [PubMed]

136. Xu, H.; Liao, C.; Zuo, P.; Liu, Z.; Ye, B.C. Magnetic-Based Microfluidic Device for On-Chip Isolation and Detection of Tumor-Derived Exosomes. Anal. Chem. 2018. [CrossRef]

137. Busato, A.; Bonafede, R.; Bontempi, P.; Scambi, I.; Schiaffino, L.; Benati, D.; Malatesta, M.; Sbarbati, A.; Marzola, P.; Mariotti, R. Magnetic resonance imaging of ultrasmall superparamagnetic iron oxide-labeled exosomes from stem cells: A new method to obtain labeled exosomes. Int. J. Nanomed. 2016, 11, 2481-2490. [CrossRef]

138. Jiang, X.; Zong, S.; Chen, C.; Zhang, Y.; Wang, Z.; Cui, Y. Gold-carbon dots for the intracellular imaging of cancer-derived exosomes. Nanotechnology 2018, 29, 175701. [CrossRef]

139. Rehman, F.U.; Du, T.; Shaikh, S.; Jiang, X.; Chen, Y.; Li, X.; Yi, H.; Hui, J.; Chen, B.; Selke, M.; et al. Nano in nano: Biosynthesized gold and iron nanoclusters cargo neoplastic exosomes for cancer status biomarking. Nanomedicine 2018. [CrossRef]

140. Rahman, M.A.; Barger, J.F.; Lovat, F.; Gao, M.; Otterson, G.A.; Nana-Sinkam, P. Lung cancer exosomes as drivers of epithelial mesenchymal transition. Oncotarget 2016, 7, 54852-54866. [CrossRef]

141. Peinado, H.; Aleckovic, M.; Lavotshkin, S.; Matei, I.; Costa-Silva, B.; Moreno-Bueno, G.; Hergueta-Redondo, M.; Williams, C.; Garcia-Santos, G.; Ghajar, C.; et al. Melanoma exosomes educate bone marrow progenitor cells toward a pro-metastatic phenotype through MET. Nat. Med. 2012, 18, 883-891. [CrossRef]

142. Liu, C.; Yu, S.; Zinn, K.; Wang, J.; Zhang, L.; Jia, Y.; Kappes, J.C.; Barnes, S.; Kimberly, R.P.; Grizzle, W.E.; et al. Murine Mammary Carcinoma Exosomes Promote Tumor Growth by Suppression of NK Cell Function. J. Immunol. 2006, 176, 1375-1385. [CrossRef] [PubMed]

143. Wieckowski, E.U.; Visus, C.; Szajnik, M.; Szczepanski, M.J.; Storkus, W.J.; Whiteside, T.L. Tumor-Derived Microvesicles Promote Regulatory T Cell Expansion and Induce Apoptosis in Tumor-Reactive Activated $\mathrm{CD}^{+}$T Lymphocytes. J. Immunol. 2009, 183, 3720-3730. [CrossRef] [PubMed]

144. Campos, A.; Salomon, C.; Bustos, R.; Díaz, J.; Martínez, S.; Silva, V.; Reyes, C.; Díaz-Valdivia, N.; Varas-Godoy, M.; Lobos-González, L.; et al. Caveolin-1-containing extracellular vesicles transport adhesion proteins and promote malignancy in breast cancer cell lines. Nanomedicine 2018, 13, 2597-2609. [CrossRef] [PubMed]

145. Lyu, L.; Wang, H.; Li, B.; Qin, Q.; Qi, L.; Nagarkatti, M.; Nagarkatti, P.; Janicki, J.S.; Wang, X.L.; Cui, T. A critical role of cardiac fibroblast-derived exosomes in activating renin angiotensin system in cardiomyocytes. J. Mol. Cell. Cardiol. 2015, 89, 268-279. [CrossRef]

146. Gomez, I.; Ward, B.; Souilhol, C.; Recarti, C.; Ariaans, M.; Johnston, J.; Burnett, A.; Mahmoud, M.; Luong, L.A.; West, L.; et al. Neutrophil microvesicles drive atherosclerosis by delivering miR-155 to atheroprone endothelium. bioRxiv 2018, 319392. [CrossRef]

147. Phinney, D.G.; Pittenger, M.F. Concise Review: MSC-Derived Exosomes for Cell-Free Therapy. Stem Cells 2017, 35, 851-858. [CrossRef]

148. Adlerz, K.; Patel, D.; Rowley, J.; Ng, K.; Ahsan, T. Strategies for scalable manufacturing and translation of MSC-derived extracellular vesicles. Stem Cell Res. 2020, 48, 101978. [CrossRef] 
149. Tang, T.-T.; Lv, L.-L.; Lan, H.-Y.; Liu, B.-C. Extracellular Vesicles: Opportunities and Challenges for the Treatment of Renal Diseases. Front. Physiol. 2019, 10, 226. [CrossRef]

150. Rohde, E.; Pachler, K.; Gimona, M. Manufacturing and characterization of extracellular vesicles from umbilical cord-derived mesenchymal stromal cells for clinical testing. Cytotherapy 2019, 21, 581-592. [CrossRef]

Publisher's Note: MDPI stays neutral with regard to jurisdictional claims in published maps and institutional affiliations.

(C) 2020 by the authors. Licensee MDPI, Basel, Switzerland. This article is an open access article distributed under the terms and conditions of the Creative Commons Attribution (CC BY) license (http://creativecommons.org/licenses/by/4.0/). 